\title{
From closed to open: A comparative stakeholder approach for developing open innovation activities in SMEs
}

\author{
Sana Saidi a , Anne Berthinier-Poncet ${ }^{\mathrm{b}}$, Allane Madanamoothoo ${ }^{\mathrm{a}}$, Wim Vanhaverbeke ${ }^{\mathrm{c}}$, \\ Simona Grama-Vigouroux ${ }^{\mathrm{a}, *}$ \\ a Y Schools Group/SCBS, 217 avenue Pierre Brossolette, 10000 Troyes, France \\ b CNAM,2 rue Conté, 75003 Paris, France \\ c Surrey Business School, University of Surrey Guildford Surrey, GU2 7XH, UK
}

\section{A R T I C LE IN F O}

\section{Keywords:}

Open innovation process Open innovation activities Stakeholder engagement SMEs

\begin{abstract}
A B S T R A C T
Recent literature on open innovation (OI) highlights the need for studies regarding the factors that influence firms to switch from a closed to an OI strategy. At the same time, stakeholder literature points out the scarcity of knowledge regarding antecedent factors fostering collaboration with the firm's stakeholders and their engagement for higher value creation. To fill these gaps, we propose an analytical framework for implementing a strategic OI process through the development of stakeholder engagement. Our framework comprises 17 factors grouped in five levers: knowledge, collaboration, organizational, strategic, and financial. We empirically applied this framework to two industrial SMEs. A qualitative study was conducted based on semi-structured interviews with internal and external stakeholders of both firms. The results show that one company successfully implemented the OI process, while the other struggled to evolve from a traditionally closed innovation model to a more open model. Analyzing the results, we identified several aspects that could explain this difference. These aspects concern the OI activities performed by both firms, the combination of the five levers into a coherent OI approach, stakeholder engagement, and the characteristics of the CEOs. The current study contributes insights for theory and practice, especially as it proposes an original framework for developing a strategic OI process that integrates a stakeholder approach.
\end{abstract}

\section{Introduction}

The increasing complexity of products and technologies, the rising costs and risks of innovation, as well as the acceleration of timeto-market have led companies to gradually shift from a closed to an open innovation system by developing new cooperation agreements and partnerships; as well as sharing ideas, knowledge, and technology with other organizations and individuals (Chesbrough, Vanhaverbeke, \& West, 2006; Durst \& Stähle, 2013). The concept of open innovation (OI) has been adopted widely over the past decade (Giannopoulou, Yström, Ollila, Fredberg, \& Elmquist, 2010; Huizingh, 2011; Lichtenthaler, 2011). However, although OI is widely discussed in large firms, much less is known about OI in small and medium-sized enterprises (SMEs). In particular, the role of stakeholders in the transition of small firms from closed to OI has not yet been studied (Brunswicker \& Vanhaverbeke, 2015; Hossain \& Kauranen, 2016; Kathan, Matzler, Füller, Hautz, \& Hutter, 2014; Vanhaverbeke, 2017a).

OI and stakeholder engagement describe similar organizational processes, and OI usually implies stakeholder engagement. Stakeholder engagement can be defined as practices undertaken by an organization to involve the firm's partners in organizational activities in a mutually beneficial way (Gould, 2012; Grando \& Belvedere, 2006; Noland \& Phillips, 2010; Svendsen, 1998; Zadek, 2001). In both approaches the focal organization reaches outside its boundaries to access essential information (Gould, 2012). Successful OI requires that firms have enough capacity to integrate the information obtained from their stakeholders into internal processes and structures (Nonaka \& Takeuchi, 2007). SMEs in general are characterized by limited assets and capabilities (Grando \& Belvedere, 2006; Rahman \& Ramos, 2010), by a less organized innovation process (De

\footnotetext{
* Corresponding author.

Email addresses: sana.saidi@yschools.fr (S. Saidi); anne.berthinier-poncet@lecnam.net (A. Berthinier-Poncet); allane.madanamoothoo@yschools.fr (A. Madanamoothoo); wim.vanhaverbeke@uhasselt.be (W. Vanhaverbeke); simona.grama@yschools.fr (S. Grama-Vigouroux)
}

https://doi.org/10.1016/j.jbusres.2019.08.016

Received 30 April 2018; Received in revised form 8 August 2019; Accepted 9 August 2019

Available online $\mathrm{xxx}$

$0148-2963$ / (C) 2019 
Toni \& Nassimbeni, 2003), and by a strong inclination to take risks and react quickly to changing environments (Parida, Westerberg, \& Frishammar, 2012). Because stakeholder engagement promotes the development of collaboration and shared goals (Gould, 2012), it enables SMEs to access information from their stakeholders (Ayuso, Rodriguez, \& Ricart, 2006; Sharma, 2005). This in turn has a positive impact on operations and profitability and can improve value creation (Laursen \& Salter, 2006; Noland \& Phillips, 2010; Van de Vrande, De Jong, Vanhaverbeke, \& De Rochemont, 2009). Collaboration with stakeholders, if not excessive (Knudsen \& Mortensen, 2011), enables SMEs to attain various advantages, such as the use of external expertise, increased creativity, and reduced rates of failure (Enkel, Gassmann, \& Chesbrough, 2009; Klijn, Eshuis, \& Braun, 2012). Moreover, it enables SMEs to compensate for their internal limitations as described above (Christensen, Olesen, \& Kjaer, 2005; Kogut, 2000; Lichtenthaler, 2008).

However, in their synthesis of the existing literature on OI in SMEs, Hossain and Kauranen (2016) mentioned that the current literature is silent about factors that foster or hinder SME collaboration with stakeholders in an OI environment. There is also scant research on the process of how SMEs, and especially small firms, move from closed to OI (Drechsler \& Natter, 2012; Vanhaverbeke, Frattini, Roijakkers, \& Usman, 2018; Wynarczyk, Piperopoulos, \& McAdam, 2013). Indeed, in the case of small firms, OI is not yet a common practice and the management tools designed to support collaboration have been primarily developed to fit the needs of larger companies (Ahn, Minshall, \& Mortara, 2015; Brunswicker \& Vanhaverbeke, 2011; van de Vrande et al., 2009; Vanhaverbeke et al., 2018; Wynarczyk et al., 2013). Consequently, most small firms lack the appropriate tools and blueprint to implement OI (Bigliardi \& Galati, 2016; Lee, Park, Yoon, \& Park, 2010; Rahman \& Ramos, 2010; van de Vrande et al., 2009). In addition, the literature has pointed out the scarcity of knowledge on how and when SMEs should collaborate with stakeholders when they make the transition toward OI (Hossain \& Kauranen, 2016). As underlined by Greenwood (2007), Shams (2016), Vanhaverbeke et al. (2018), and Vanhaverbeke (2017a), research is still underdeveloped on the attributes of the relationship between the organization and its stakeholders, and on the practices to be developed by OI entrepreneurs to become effective orchestrators of their stakeholder networks.

Based on these gaps, we formulate the following research question: "How do SMEs, and more precisely small firms, collaborate with stakeholders in the process from closed to OI?"

Focusing on the stakeholders involved in the OI process, when addressing this research question, we first identify the factors that could facilitate and hinder stakeholder engagement in the process of going from closed to OI. We then propose a framework for analysis, which is inspired by the work of Bigliardi and Galati (2016) and Berthinier-Poncet, Grama, and Saidi (2017), who highlighted the main barriers blocking the adoption of OI in SMEs (knowledge, collaboration, organizational, financial, and strategic barriers). The framework will be further refined with SME managerial practices and success factors found in the OI literature. Second, we apply this framework empirically through a qualitative in-depth examination and comparison of the OI process in two small industrial firms, one in France and the other in Belgium. Indeed, finding successful examples of OI practices in small firms is not an easy task (van de Vrande et al., 2009; Vanhaverbeke et al., 2018; Wynarczyk et al., 2013), so we consider that our empirical field could offer an interesting contribution for academics and practitioners. After presenting the results of our comparative study, we highlight and discuss the main levers and OI activities facilitating or hindering the process from closed to OI. Finally, we present the contributions and limitations of our study.

\section{Literature review}

\subsection{How does stakeholder theory contribute to the OI field?}

The OI field and stakeholder theory involve similar processes, as they both focus on the willingness of organizations to collaborate with various partners to increase value creation (Vanhaverbeke \& Cloodt, 2006). The connection of stakeholder theory to the OI field could facilitate the understanding of the relationships that an organization has with its stakeholders involved in the OI process.

Stakeholder theory stipulates that managers who want to optimize their firm's success will consider broader stakeholder interests. For this purpose, they are expected "to manage and integrate the relationships and interests of shareholders, employees, customers, suppliers, communities and other groups in a way that ensures the long-term success of the firm." (Freeman \& McVea, 2001, p. 199). The stakeholder management concept helps organizations identify and analyze the stakeholder's characteristics that influence, or are influenced by, the organization's behavior and decisions (Freeman, 1984). The principal assertion of stakeholder theory is that, in order to survive and earn approval, a firm must consider the claims of its stakeholders (Freeman, Wicks, \& Parmar, 2004).

The term "stakeholder" has different meanings according to different academic disciplines. Stakeholders as defined by Freeman (1984, p. 25) are "any group or individual who can affect or is affected by the achievement of the firm's objectives." Stakeholders can be divided into internal and external parties (Neubaum, Dibrell, \& Craig, 2012; Parmar et al., 2010). Internal stakeholders oversee the management, marketing, design, purchasing, manufacturing, assembly, and sales activities of the firm (Nilsson \& Fagerström, 2006); whereas external stakeholders are the firm's customers, distributors, suppliers, regulators, communities, governments, and legislators (Harrison \& St. John, 1996). The two categories have different roles for the organization. For instance, internal stakeholders are important for project portfolio management (Beringer, Jonas, \& Kock, 2013), whereas external stakeholders can influence product success rates, manufacturing efficiency, and/or the acquisition and development of particular knowledge and skills (Harrison \& St. John, 1996; Markovic \& Bagherzadeh, 2018; Vanhaverbeke et al., 2018).

The engagement of internal and external stakeholders represents a key success factor for value creation (Gould, 2012; Greenwood, 2007). Gao and Zhang (2001) consider stakeholder engagement as a "developmental exercise" that involves "mutual understanding." As stated by Noland and Phillips (2010, p. 40), stakeholder engagement "is used to recommend a type of interaction that involves, at minimum, recognition and respect of common humanity and the ways in which the actions of each may affect the other." For Greenwood (2007), stakeholder engagement induces the involvement of stakeholders in a positive manner and for mutual benefit.

By these definitions, stakeholder engagement appears not only perfectly adapted to the OI context but even essential (Gould, 2012). In OI, firms interact with their stakeholders through OI projects that involve partnerships and mutual working relationships between two or more parties aimed at developing new products, technologies, or services (Chesbrough \& Schwartz, 2007). Stakeholders involved in OI can be defined as individuals or organizations that are affected by an OI project and have an impact on the project through their demands and collaboration. These stakeholders have an interest in an OI project and the power to decide whether to facilitate or hinder its evolution and results (Ballejos \& Montagna, 2008). These stakeholders are at the heart of the product development process (Chesbrough \& Prencipe, 2008). 
OI consists of a propitious use of knowledge from external and internal stakeholders, resulting in different types of innovative products and processes (Chesbrough et al., 2006; Gassmann, Enkel, \& Chesbrough, 2010). Stakeholder engagement strengthens the organizational competencies related to knowledge exploration, knowledge retention, and knowledge exploitation (Ayuso et al., 2006), that are mandatory for OI (Lichtenthaler \& Lichtenthaler, 2009). In the OI context, a firm is systematically performing knowledge exploration, retention, and exploitation inside and outside of the firm's boundaries (Lichtenthaler, 2011). Knowledge exploration concerns the selection of the most appropriate ideas generated inside or outside the firm (Lichtenthaler \& Lichtenthaler, 2009; Zollo \& Winter, 2002). In contrast, knowledge exploitation relates to the replication of the new approaches in diverse contexts (Lichtenthaler \& Lichtenthaler, 2009; Zollo \& Winter, 2002). Finally, knowledge retention encompasses maintenance of the knowledge over time, both inside the organization (Garud \& Nayyar, 1994) and outside in a firm's interorganizational relationships and alliances with its OI stakeholders (Gulati, 1999).

Relationship building through stakeholder engagement becomes a key element for the processes of knowledge exploration, retention, and exploitation that are essential for OI (Gould, 2012). However, these relationships with OI stakeholders will be handled differently by large firms and SMEs, as SMEs are usually characterized by a scarcity of resources and informal management of relationships (Parida et al., 2012; Van de Vrande et al., 2009; Vanhaverbeke et al., 2018).

\subsection{How do SMEs engage their stakeholders in the OI process?}

In an OI environment, SMEs collaborate with a pool of different kinds of stakeholders, such as: universities and other higher education institutions for scientific ideas (Bianchi, Cavaliere, Chiaroni, Frattini, \& Chiesa, 2011); R\&D institutes for developing new technologies (Asakawa, Nakamura, \& Sawada, 2010; Bianchi et al., 2011); governments for stimulating innovations directly or indirectly (Bianchi et al., 2011); incubators for idea generation (Gassmann \& Enkel, 2004); large companies for joint product-development projects (Gassmann et al., 2010); other SMEs (Van de Vrande et al., 2009) for developing and commercializing innovations; entrepreneurs for suggesting new solutions (Gassmann \& Enkel, 2004) and other actors (e.g., suppliers, clients, competitors, non-competitors, affiliates or consultants) for their role in the relationships.

SMEs cannot gain access to external resources for innovation as easily as larger firms. The main purpose of developing a network of partners is to enable them to reach outside their boundaries for additional-sometimes essential-information that they may not otherwise have access to (Gould, 2012; Lee et al., 2010). The limited financial and human resources of SMEs constrain their capabilities to scan and monitor their environment to search for competitors, potential collaborators, and customers. When compared to SMEs with high-level technical facilities, which often collaborate with universities and research centers, SMEs with lower-level technical facilities are less motivated to promote research and identify their needs to improve innovation through an appropriate market analysis. The lack of adequate resources, financial and otherwise, also makes it difficult for some SMEs to create medium- or long-term plans to attain a stronger research output. Most SMEs in this category only focus on short-term marketing. All of these difficulties highlight the importance of the ability of SMEs to engage stakeholders in their ambition to innovate and develop orchestration skills to successfully manage the various stakeholders in the network.

Engagement, according to Waddock (2001), involves a process of dialogue and leads to relationship development (Gould, 2012). As a result, SMEs that intend to develop OI processes find it necessary to build effective collaboration and deep and long-lasting ties with stakeholders (Gould, 2012; Lee et al., 2010). Consequently, there is a need to find a balance between the expectations of the organization and its internal stakeholders and those of its external stakeholders. It is not easy to balance the interests of the stakeholders in large stakeholder networks or in those that include a variety of stakeholders (Roloff, 2008). Therefore, collaborating effectively with relevant stakeholders becomes a key element of value creation in an OI setting (Gould, 2012), and a better understanding of stakeholder needs and desires facilitates the creation of win-win situations (Greenwood, 2007; Plaza-Úbeda, Burgos-Jiménez, Vazquez, \& ListonHeyes, 2009).

Important factors for successful collaboration with stakeholders include communication and trust (Antonacopoulou \& Meric, 2005). As Miles et al. (2006, p. 197) highlighted, "for effective strategy to occur, there should be a channel for honest, unfiltered information to flow from the BSEs [boundary spanning employees] who directly interact with stakeholders and technology and strategy making top executives." Katsoulakos and Katsoulacos (2007) also pointed out that organizational knowledge development is based on the support given by collaborations with stakeholders. Similarly, Ayuso et al. (2006) found the ability to integrate the knowledge obtained from stakeholders to be an important organizational competency. However, collaboration with stakeholders can encounter many challenges in the context of OI. The SME management team is a central player, tasked with understanding and balancing the interests of different stakeholders (Greenwood, 2007). SME managers not only have to find a way to understand the expectations of stakeholders in an OI project; they also have to detect conflicts at an early stage. In sum, numerous factors could facilitate or hinder collaboration with stakeholders in an OI environment.

Therefore, and as suggested by Gould (2012), linking stakeholder engagement and OI could facilitate the understanding of the factors fostering or hindering the development of OI within SMEs. However, no systematic attempt has yet been made to better understand openness decisions by firms (Drechsler \& Natter, 2012), much less to offer a strategic framework for developing an OI process compatible with the corporate strategy and business orientation of SMEs (Drechsler \& Natter, 2012; Gould, 2012).

\subsection{Proposition of a framework for a strategic OI process}

OI literature has focused on additional factors that could influence collaboration with stakeholders involved in OI. For instance, one of the factors that causes many challenges in OI is related to financial issues (Enkel et al., 2009; Van de Vrande et al., 2009). Indeed, collaborating with external stakeholders is a costly process (Du Chatenier, Verstegen, Biemans, \& Omta, 2009) compared to the closed innovation model (Knudsen \& Mortensen, 2011). The collaboration process with stakeholders entails numerous other factors, such as the loss of know-how (Bigliardi \& Galati, 2016) and the challenges of finding the right partners (Van de Vrande et al., 2009). Different studies also highlight some internal factors related to the managerial competencies needed to work with stakeholders (Van de Vrande et al., 2009; Verbano, Crema, \& Venturini, 2015). Other factors are related to the difficulty of accessing relevant knowledge, which in turn could limit the firm's ability to adopt OI (Van de Vrande et al., 2009).

In an attempt to determine factors hindering the adoption of OI in SMEs, Bigliardi and Galati (2016) identified four main barriers: knowledge, collaboration, organizational, and financial/strategic. We use this framework and consider these barriers mainly as levers that could either positively or negatively impact the development of stakeholder engagement in the OI activities of SMEs. However, we 
relate managerial practices and success factors found in the OI literature in SMEs to each lever, resulting in the identification of 17 potential factors fostering the use of OI in SMEs (see Table 1). Construction of the analytical framework was also based on a previous paper (Berthinier-Poncet et al., 2017) on OI practices in clustered SMEs. In Table 1 (Framework proposal for OI organizational intention), of the 17 factors identified, we only kept eight factors from Bigliardi \& Galati's proposition and developed nine additional factors from the literature review on OI in SMEs. Moreover, Bigliardi and Galati (2016), using PCA analysis, identified one lever that combined financial and strategic factors. In our study, we separate these factors as they focus on different organizational objectives.

Consequently, we propose the following five levers:

The knowledge lever is related to all the knowledge management activities that assure the prerogatives for an organization to build effective collaboration with its OI stakeholders. Knowledge management involves processes such as the identification, assimilation, and leveraging of the internal and external knowledge to help a firm better compete (Laursen \& Salter, 2006; Von Krogh, 1998). For a firm to gain greater innovativeness and responsiveness, it is essential to have access to the knowledge of its stakeholders. For instance, some studies have suggested that in relationship with customers (a type of external stakeholder), knowledge management helps firms increase the quality of customer solutions by offering pertinent solutions and becoming more customer focused (Davenport \& Klahr, 1998).

To access internal knowledge, a firm needs to develop the internal learning capacity that occurs when internal stakeholders, who are part of the organization, create and transfer new ideas and knowledge inside the firm boundaries (Bontis, Crossan, \& Hulland, 2002). As for external knowledge, this relates to the firm's absorptive capacity - that is, its ability to recognize the value of new external information, assimilate it, and apply it to commercial ends (Cohen \& Levinthal, 2000). In endeavoring to manage the internal and external information from its stakeholders, a firm needs to implement a knowledge infrastructure, including technical tools and programs that will help the firm's internal stakeholders share, collaborate, and communicate (Davenport \& Prusak, 1997).

Knowledge management also involves the management of intellectual property (IP). According to Kalanje (2006, p. 2), "IP refers to unique, value-adding creations of the human intellect that result from human ingenuity, creativity and inventiveness." Intellectual property rights (IPRS) must therefore be managed carefully, especially when SMEs buy external IP or sell unused internal IP (Chesbrough, 2003; Lee et al., 2010; Van de Vrande et al., 2009), since their role is to ensure and encourage investment in innovation. The literature has pointed out the challenges to SMEs in managing IP in the OI context. For instance, organizations need to protect their knowledge and skills to preserve the value created through their innovation. However, with OI, they are asked to cooperate with other parties and share knowledge (McEvily, Eisenhardt, \& Prescott, 2004; Vanhaverbeke, 2006). The right balance must thus be found to control and manage access to knowledge.

The collaboration lever is related to the level of embeddedness in networks, but also to the ability of a firm to resolve conflicts, advance shared visions, or recognize the benefits of working together. More specifically, collaboration is linked to the issues of finding the right stakeholders in terms of knowledge, values, organizational, and cultural issues (Bigliardi \& Galati, 2016; Enkel et al., 2009; Van de Vrande et al., 2009). Studies highlight the positive impact of strong and positive relationships with OI stakeholders on incremental innovation and value creation (Gould, 2012; Kaufmann \& Tödtling, 2001; Laursen \& Salter, 2006; Noland \& Phillips, 2010). Prior research has also shown that a firm's strong ties with its stakeholders could affect incremental innovation; whereas a relationship with weak ties could affect radical innovation (Elfring \& Hulsink, 2003). For this reason, it is important to choose the right stakeholder with which to build a long-lasting collaboration since, as Vanhaverbeke (2017b, p. 9) highlighted, "once you start co-operating, you have to stick with them. You have to share the good and the bad times." An effective and long-lasting relationship is even more important in SMEs than in big firms, since SMEs usually rely on good and direct personal relationships with stakeholders (Vyakarnam, Bailey, Meyers, \& Burnett, 1997) to fulfill their needs for resources, money, and services to achieve their sustainable growth (Spence, Schmidpeter, \& Habisch, 2003).

Bad collaboration in the areas of openness and collaboration could create hazards regarding innovation property ownership (Cassiman \& Veugelers, 2002; Henkel, Shoberl, \& Alexy, 2014; McEvily et al., 2004); one such hazard is the risk of opportunistic behavior by OI partners (De Faria \& Sofka, 2010). Trust is therefore crucial for SMEs, especially when IP is involved, because of their lack of financial resources to assume the cost of intellectual property protection mechanisms (IPPMs) - whether they are applying for IPPMs or dealing with litigation because of counterfeiting or infringement.

Different strategies can be used in the selection of stakeholders. For instance, crowdsourcing could be a way to find the right stakeholders for OI projects. Crowdsourcing is related to the notion of cocreation between producers and consumers for the purpose of value creation (Geiger, Rosemann, \& Fielt, 2011). A crowdsourcing platform can therefore be used as a tool for discussion and finding new partners with different profiles and cultures.

However, it is important to handle the collaboration with multicultural stakeholders carefully since cultural gaps with a myriad of different stakeholders can make it difficult to fulfill mutual goals. Literature attests to the difficulty of working with different cultures and profiles in OI projects, sometimes leading to constraints for the evolution of the project (Du Chatenier et al., 2009). Indeed, misunderstanding the other party can affect a project negatively, impairing or even destroying mutual trust and confidence among the different parties (Yitmen, 2015).

The organizational lever refers to the managerial skills needed to manage OI projects and to establish effective collaboration with the stakeholders involved in OI (Bigliardi \& Galati, 2016; Teirlinck \& Spithoven, 2013; Van de Vrande et al., 2009; Verbano et al., 2015). Stakeholder management needs to be correlated with the goals of the organization (Ackermann \& Eden, 2011). Employees, seen as internal and salient stakeholders, play a significant role (Mitchell, Agle, \& Wood, 1997). The way employees are managed influences their collaboration with each other and with other potential stakeholders (Greenwood, 2007). Moreover, a centralized decision-making process and the administrative and legal burdens inherent in such a process might lead to difficulties in the implementation of the OI process, as well as resistance to change and a lack of motivation and commitment by employees (Bigliardi \& Galati, 2016; Van de Vrande et al., 2009).

The strategic lever represents the strategic vision of the firm regarding OI. The characteristics of the CEO, as well as the existence of a strategic vision regarding OI, influence the adoption of OI processes in SMEs (Ahn, Minshall, \& Mortara, 2017). OI strategy is an important resource for the success of collaboration with OI stakeholders; it focuses on a change in the firm's business model toward more openness (Van de Vrande et al., 2009). If an OI project lacks adequate and appropriate planning, this lack can trigger difficulties in completing the project (Du Chatenier et al., 2009). For instance, if the firm's management decides to implement a technical tool to support OI process, but fails to explain its real purpose and strategy, it could face considerable resistance from stakeholders (Du Chatenier et al., 2009). Previous literature has also shown that a lack of knowledge of the OI strategy could generate fear about continuing the 
process (Keupp \& Gassmann, 2009). Additional factors could be related to the strategic lever, such as the motivation of management to become involved in OI projects (Lee et al., 2010) and the value creation potential of OI projects (Hughes, Ireland, \& Morgan, 2007).

Finally, the financial lever represents both the economic and the financial issues of the OI process (Teirlinck \& Spithoven, 2013). According to research on the difficulties SMEs face when they engage in OI, many of these difficulties come from a lack of funding (Spithoven, Vanhaverbeke, \& Roijakkers, 2013) or a lack of resources; these in turn affect manufacturing, distribution, marketing, $\mathrm{R} \& \mathrm{D}$, or recruitment of researchers (Lasagni, 2012; Lee, Park, \& Song, 2009). Other studies have suggested that financial support in OI projects is often inconsistent and inadequate (Du Chatenier et al., 2009). Financial resources thus have a direct impact on the success of OI projects (Du Chatenier et al., 2009), and this is especially true for SMEs since OI can be expensive (Christensen et al., 2005). For instance, the use and enforcement of IPRs, mentioned above, to control and manage access to knowledge can be challenging for SMEs due to the lack of financial resources and enforcement abilities. As a result, limited financial resources and high costs could hamper the success of collaboration with OI stakeholders in SMEs.

Our analytical framework for OI organizational intention is summarized in Table 1.

\section{Data and method}

\subsection{The choice of the qualitative approach and of the multiple-case studies design}

We have chosen an exploratory qualitative approach because of the lack of knowledge regarding antecedent factors fostering collaboration with the firm's stakeholders and their commitment to higher value creation, which addresses the lack of qualitative studies on OI in SMEs (Usman, Roijakkers, Vanhaverbeke, \& Frattini, 2018). However, we argue that analyzing the levers facilitating or hindering the adoption of OI can only be understood by obtaining information from SME managers and external stakeholders who share their OI experiences. To deepen our understanding of these levers, we need a qualitative methodology that produces in-depth and illustrative information that sheds light on the various dimensions of the problem under analysis, and represents the views and perspectives of both external and internal stakeholders (Eisenhardt \& Graebner, 2007; Yin, 2016). In addition, in their systematic literature review, Hossain and Kauranen (2016) suggested the need for qualitative studies when investigating the process of OI implementation in SMEs. Qualitative research is also appropriate for a stakeholder approach in SMEs as it focuses on understanding the dynamics of social relations (Yin, 2016).

For our qualitative study, we chose a multiple-case study design to explore a phenomenon (the replication strategy) and provide a strong basis for theory building (Eisenhardt \& Graebner, 2007; Yin, $2003,2009)$. The use of replication strategy means that the outcomes from one case study are compared and contrasted with the findings from other case(s). Relying on replication strategy adds more external validation to the findings since case studies depend on analytical rather than statistical generalizations (Yin, 2003, 2009). Multiple case studies provide a comparison of the data collection across different sites, which can be useful to improve our understanding of the phenomenon under study (Eisenhardt \& Graebner, 2007). Therefore, we examined the phenomenon related to the factors that could facilitate and hinder collaboration with stakeholders in an OI environment by interviewing the internal and external stakeholders of two European SMEs: Norelem France, a small French manufacturer of standard parts and machine elements; and Curana, a small Belgian manufacturer of bike equipment and bike accessories.

\subsection{Justification for the case studies}

The two firms share similarities in terms of industry (both were original equipment manufacturers-OEMs) and in terms of size (both are small firms with $<50$ full-time employees). We have focused on two small firms because previous research struggled to find good examples of OI implementation in these contexts (Ahn et al., 2015; Kathan et al., 2014; Vanhaverbeke et al., 2018; Wynarczyk et al., 2013). Moreover, managing OI in small companies is a very specific process, requiring further examination in order to make it more accessible for entrepreneurs (Vanhaverbeke et al., 2018). OI is not a commonly used practice in small firms and only a few are knowledgeable about how to develop innovation through partnerships (Kathan et al., 2014; Spithoven et al., 2013; van de Vrande et al., 2009; Vanhaverbeke et al., 2018).

Although both of our focal firms engaged in an OI process, they have not reached the same level of openness: Norelem is struggling to improve its OI development, whereas Curana has reached an interesting level of openness in its innovation process thanks to its stakeholder engagement. It is precisely this difference in terms of OI strategic development that interested us when selecting both cases. In contrasting the two companies (as a strong and a weak OI application), we applied the opposing cases method suggested by Eisenhardt and Graebner (2007). This method is used to analyze data both within and across each situation and helps us to clarify whether the findings are valuable or not (Eisenhardt \& Graebner, 2007).

As it is difficult to find SMEs with good OI expertise (Kathan et al., 2014; Spithoven et al., 2013; Vanhaverbeke, 2017a), the case of Curana, which has been implementing OI successfully since the early 2000s, gave us an excellent opportunity to draw a comparison with Norelem. Comparing the cases reveals how far SMEs must go to be successful with OI, something which has not been previously studied in the literature, as the benefits of OI are usually considered without taking the implementation issues into account.

\subsubsection{Description of Norelem France}

Created in 1943, Norelem France is based in the French region of Aube Champagne, a region that formerly specialized in the textile industry, but which is today facing economic reconversion. Awarded in 2016 with a "Company of the Year" prize by the CGPME (General Confederation of Small and Medium-sized Enterprises), Norelem France is representative of the region's SME renewal. Comprising 48 employees, Norelem France is an OEM that makes a broad range of precision machinery parts and has been at the forefront of innovation since the 1970s. Norelem is considered a highly reliable and innovative partner. Norelem France was owned by an American group from 1991 to 2000, then in 2000 it was bought by a German group that sought to consolidate Norelem with the rest of its group. This was a difficult period, especially as Norelem suffered from several years of underinvestment, but the German parent company eventually decided to reinvest and recapitalize the French SME. Through these periods of foreign ownership, Norelem France has been led by the same CEO, who is fully committed to steering the company toward a more strategic OI process and views this as a necessity for creating additional value.

\subsubsection{Description of Curana}

Curana is a third-generation business founded in the 1940s in Ardooie, Belgium. Two grandsons of the founder, brothers Dirk and Geert Vens, took over the company in the 1990s. Curana is an OEM that makes bike equipment and bike accessories such as bag carriers 
and mudguards for several Belgian bicycle manufacturers. Curana now has 30 employees. Over time, accessory suppliers struggled with increasing price pressure from bicycle manufacturers. By the 1990s, the market was shifting toward global competition and European bicycle manufacturers started sourcing internationally for less expensive accessories. Most bicycle part producers could not withstand this fierce competitive pressure.

With market conditions deteriorating rapidly, in 1999 Dirk Vens decided to dramatically reorient the company's strategy. His idea was to conceive, develop, and produce products that were completely new to the industry. As the firm had no skills in design and plastics, it had to rely on OI. After three years of highly intense work, Curana's new mudguard (the B-Lite) was a major success. The way in which the company manages the innovation network has been considered as a best practice (Vanhaverbeke, 2017a, 2017b).

Over the past 20years Curana has switched its business model three times as a result of its OI. It first switched from an OEM to an ODM (original design manufacturer) strategy. As ODM, the firm could now set its own prices and avoid price competition. In 2006 it moved from an ODM to a proactive design strategy because the firm developed strong design skills internally and in its partner network. This, in turn, led to several design and innovation awards, giving the firm high visibility. Curana used this visibility to build a branding strategy in 2008.

\subsection{Data collection}

The present study uses data from both the Norelem France and Curana case studies to investigate the factors that could promote or hinder the implementation of a more strategically oriented OI process and foster stronger stakeholder engagement.

In the case of Norelem, the data collection process lasted from April 2017 to February 2018 and comprised a total of fourteen faceto-face semi-structured and in-depth interviews with various internal and external stakeholders. There were two main stages in the data collection. For the first stage, we conducted three in-depth exploratory interviews with Norelem's CEO and two managers to understand the firm's point of view regarding the OI process. We also spent a day at Norelem's production site, which allowed us to observe how they operate and the latest technologies developed together with their external partners. On this visit, we conferred with the CEO to develop a list of internal and external stakeholders to be interviewed. In the second stage, we created an interview guide on the main sources and difficulties of OI. We then used this interview guide and carried out 11 semi-structured interviews, lasting $1 \mathrm{~h}$ on average: six with internal stakeholders (noted as I for the coding), such as the purchase and supply manager, the communications officer, the R\&D manager, the factory and cross-cutting project manager, and the quality manager, and repeated interviews with the CEO (who is also in charge of commercial activity); and five interviews with external stakeholders (noted as E) who were involved in various co-development innovative projects (SMEs, MNEs, and academic institutions) (see Table 2 for the details of these interviews).

To triangulate our data and increase its analytical robustness, we collected additional data by means of direct observation and by reading external (website, institutional brochures, and catalog) as well as internal documentation (activity reports, market surveys, and strategic studies).

The case of Curana is slightly different since it has been extensively documented in previous publications (Vanhaverbeke, 2017a \& 2017b). For these publications, nine interviews were conducted with several stakeholders, including the CEO of Curana, two designers, a Curana production engineer, and several external stakeholders such as a polymer extruder, a technical centre, a lock manufacturer, and two clients. Most information about Curana is based on these interviews from 2010 and the data we collected from the company, which was quite extensive. We approached Curana again in 2018 for new interviews based on the same set of questions used in the case of Norelem and we interviewed the CEO and a leading designer who is a strategic supplier.

Extensive interviews were carried out for the Curana case study, and the company has been under study for 8years now. Saturation was originally reached by double checking with suppliers, customers, and complementors of Curana and with secondary materials. In the long run, we can verify whether specific claims and statements are true or not. A longitudinal approach to data gathering is very powerful as claims can be checked over time: Did they materialize or not, and if not, why? Moreover, only two interviews were taken into consideration in 2018 as the OI practices have not substantially changed and therefore a lot of information would be redundant compared to the original interviews realized in 2010.

The interviews from 2018 lasted between $45 \mathrm{~min}$ and $1 \mathrm{~h}$ each (see Table 2 for more details). We also used the same interview protocol in 2018 as that used for Norelem, and so aligned the interviews for both companies.

\subsection{Data analysis}

Data analysis was performed in two stages. First, to ensure the validity and quality of data processing, the interviews were coded separately by the researchers after being recorded and transcribed. We used the analytical framework built from the literature with the 17 factors affecting collaboration with stakeholders in an OI environment (see Table 1).

Once the coding was completed, we proceeded to the second stage of our analysis by examining data extracted from the interviews. In this way, we carried out two types of analysis for each case. We began with vertical interview-by-interview analyses to discover what each individual answered for all given factors, and then performed horizontal analyses for each of the 17 factors. From this point, we proceeded to synthesis (both horizontally and vertically) to obtain a global vision related to the studied factors. These analyses clarified the individual and collective points of view of the interviewees regarding the factors that affect collaboration with stakeholders in an OI environment.

\section{Results}

The findings are detailed according to the five main levers mentioned in Section 2.3. In Table 3 we categorized these factors as "actions in place" (actions already implemented within Norelem and Curana) and "required actions" (to be implemented for a more successful openness of the innovation process).

The knowledge lever relates to internal learning ability, absorptive capacity, and IP management. Norelem has some actions in place that support internal learning and deliver to employees the skills needed to work on different innovative projects. For example, Norelem's managers are confident that they offer their employees the appropriate training and software for successful product development. Moreover, the firm facilitates employee participation in some ideation process and brainstorming sessions.

At Curana, employees had to learn new skills as the company switched from an OEM to a design-based business model, turning design into the main differentiator for the Curana product range. Design was new to the company and was originally sourced from an external design house. Curana then integrated design as its main internal competence, yet design and innovation are organized as part of a 
separate company known as Curana Invest (where a few external designers also work).

Norelem is also implementing actions concerning its absorptive capacity to involve its external stakeholders. For instance, its employees are motivated to capture external information related to market changes, technological advances, and external patents via their participation in various events such as exhibitions and conferences. Customer and supplier feedback is exploited to increase internal innovation (I3: "We listen to both the current needs as well as the future needs of our customers. Our interest is related to customer requests that will lead us to make developments, new products, new concepts or new features to develop."). Norelem also developed a collaborative platform called Creative Island to facilitate co-creation and capture external knowledge, where clients can reveal their insights about products and create their own products (I4: "Creating a product and appealing to general public opinion reminds me right away of the collaborative platform, the operation called Creative Island."). Despite all these initiatives to find information and knowledge from external stakeholders, the CEO still complains that the company lacks the skills to better capture external information.

Curana has a well-developed process for absorbing and integrating knowledge and ideas from external stakeholders. Curana innovates on a continuous basis with a range of partners, including suppliers, universities, producers of complementary products, designers, and creative people in other industries. Those partners have known each other for more than a decade and they work together with trust built over the years. The variety of partner knowledge and skills, the accurate understanding of each other's skills, and the openness among them enables Curana to surprise the market year after year with novel products. Curana's CEO comments: "We are much smaller than large firms with big R\&D budgets, but the network with external partners puts us in touch with much more and highly novel ideas compared to a firm that is mainly working with internal R\&D people."

Regarding IP management, Norelem already holds several patents, but it is more open to buying external IP. According to the $\mathrm{CEO}$, the strategy is to innovate quickly and make the copying process more difficult for competitors. Despite all the initiatives that support the assimilation and the dissemination of knowledge, internal stakeholders (except the CEO and the R\&D manager) testify that they are not really knowledgeable about the innovation projects developed inside the firm. The CEO is aware that they lack shared goals and commitment between internal and external stakeholders (I6: "We have a deficiency in the field the federation [of the internal and external stakeholders].").

Curana also holds some patents, but this company's strategy is built on fast design and change rather than IP protection. Co-development of new products and technologies also requires arrangements regarding IP. Curana and its partners agree not to go for co-ownership because this leads to complex situations with regard to IP, among other matters. Instead, they make agreements about who will own the technology and how other partners can license the technology on a royalty-free basis for a specific period and a specific application area. These rules have led to a conflict-free collaboration for 15years.

The collaboration lever includes all the factors that are essential for the collaboration process with stakeholders in OI. Regarding the issues of finding the right partners for the OI process, Norelem collaborates with some external stakeholders, mainly clients and suppliers. It also relies on lead users for the development of new products. Moreover, the firm collaborates with universities by hiring some $\mathrm{PhD}$ students and also by co-developing software with a research lab at the Technological University of Troyes (UTT). The external stakeholders commit to involvement in these projects because they consider Norelem trustworthy. Despite this close collaboration, Norelem is perceived by its external stakeholders not as a real innovation partner, but rather as a "second-tier" supplier that is very dependent on its product catalog. Furthermore, Norelem lacks software to manage external stakeholders involved in OI, so there is no appropriate follow-up of all exchanges. Norelem also attempts to have some OI initiatives with its internal stakeholders, although these are neither frequent nor formalized. To foster collaboration, the team of internal stakeholders is composed of people from different departments, such as sales, administration, or R\&D. Moreover, the CEO and other managers are aware of the fact that the OI initiatives are not managed through a proactive and formalized process and this is leading to suboptimal results.

Curana started OI in 1999 with just a few partners. It started with an innovation project with a design house, a polymer extruder, and a lead user. The project led to the successful introduction of a radically new and premium priced mudguard for bicycles. Over time, Curana increased its number of partners and included different organizations with a wide variety of skills. The firm was soon recognized as an innovation leader in the industry and it attracted many potential collaborators, both locally and internationally. Curana found that it needed to be diligent in selecting the right partners. Today Curana's reputation and visibility makes it easy to find partners. However, as Curana is continuing to globalize and its network of partners is including new partners from other continents, managing them is proving difficult because of differences in business approach, language, and culture.

Concerning the types and frequency of these relationships, all of Norelem's managers are aware that they are working with strong-tie stakeholders. This close collaboration was also confirmed by Norelem's external stakeholders (E1: "So we [Norelem and the external stakeholders] have known each other well for a long time and we work in a close relationship and pool our efforts and actions together... it was for me a model partnership... it was an exemplary partnership."). Norelem's CEO is aware of the importance of weak-tie relationships for radical innovation processes, but he said that he does not have a strategy in place to manage these types of relationships. The involvement in OI of the stakeholders remains limited and isolated (I6: "I would say that collaboration with the external stakeholders is limited.").

Curana also has strong ties with its partners. Most are trusted partners with whom the company has been working for 10 to 15years. In contrast with Norelem, the collaboration with Curana's partners is never "limited" or "marginal". Collaboration with Curana is important for most partners, as it constitutes a substantial part of their income. Partners can benefit directly from successful innovation projects with Curana, and only those partners whose skills are indispensable are part of an innovation project. Curana's CEO understands the competence of his partners perfectly, which allows him to speed up and get the most out of the innovation projects.

Norelem has stakeholders with very different profiles, from equivalent SMEs to multinationals. However, some of Norelem's managers complained about the difficulties of working with various partners with differing profiles and cultures (I6: "The first difficulty is the notion of meaning and semantics because when we worked with our old partners we had the same technical semantics and the same technical culture as they do. But when we want to work in an open environment, we would be in a completely different field of meaning."). Regarding potential opportunistic behavior during the OI processes, the CEO is aware of the potential loss of control as the information and technology is shared among more parties (I2: "I think that the problem we may eventually encounter is in the rigor of the monitoring and the structure of the project').

Curana worked on its first OI projects (1999) with value chain partners from the same region. Those partners were all small companies located in the same region of Europe as Curana. Short distances 
allowed for frequent face-to-face contacts to solve problems quickly. The partners shared the same business values and cultural norms, which significantly helped the collaborative innovation process. Values in the network such as open communication, open bookkeeping (looking after the weakest links in the partner network), and consultation with partners kept relations constructive, transparent, and conflict free. Opportunistic behavior was kept to a minimum because of open communication and transparency. Partners who did not respect the agreements in the network were expelled (which is the locus of creativity and innovation) or forced to stay in line.

The organizational lever focuses on all internal managerial factors that could influence the relationship with OI stakeholders. To centralize all of its innovation projects, Norelem has a small R\&D structure formed of three persons. There is also an agreement among all the internal managers that the decision-making process is to be centralized and reliant on approval from the CEO. In this way, decisions regarding OI projects are not always communicated to other members of the organization. For example, when the R\&D department decides to initiate a new product development project, it only asks the purchasing department to acquire the appropriate materials; it does not inform them about the details of the OI project.

For Curana, successful innovation depends not only on its own internal innovation unit but also on the way the network of external partners is managed. Curana's external network-similarly to Norelem-is personally managed by the CEO. His role as an entrepreneur is to ensure that all partners work toward the common goal of commercializing highly innovative ideas, that they benefit from the network (win-win logic), and that they stay on board even when problems emerge. The internal innovation and design unit is very small and enables dedicated people from the outside to work in continuous collaboration with internal people. Daily meetings of employees in the company guarantee that everyone is informed and that they can each bring in their own point of view. This is a relatively new organizational practice, as departments previously worked separately, leading to various kinds of operational problems and tensions between employees.

Despite the fact that Norelem is putting in place some managerial actions to facilitate collaboration and creativity, such as the aforementioned creativity and brainstorming sessions, the company lacks procedures to organize collaboration. These events are organized in an ad-hoc manner and lack formalized procedures. The organizational culture of Norelem tends to focus on opportunistic initiatives of collaboration. At Norelem, communication with employees is mainly oral, and as a result, internal managers (except for the R\&D manager) are unable to detail the innovation strategy and the firm's OI projects. Despite the expressed desire to develop a more open and innovation-oriented organizational culture, in practice communication about the OI projects is limited and occasional. Internal stakeholders at Norelem report that there are no electronic tools to communicate news about innovation projects (I4: "We are lucky to be an SME with less than 50 people, so the exchanges are made daily, in the corridor.").

Communication between employees at Curana is similarly unstructured, but the company's daily meetings make it possible for strategies, problems, and differences to be discussed openly. Alignment of views is considered part of the job, and not as a lucky outcome of informal discussions in the corridor. It is also important to underscore the role of the CEO in infusing the values in the company and the partner network. He is a firm believer in OI and he is continuously focusing on the need for partners to work collaboratively and in consultation with one another, to communicate openly, and to discuss and solve problems and conflicts early on. In his view, doing things without consultation is a quick way to break trust.
The strategic lever encompasses the strategic vision that could affect collaboration with OI stakeholders, but also the motivation and expected impact of OI projects. Norelem is torn between two innovation strategies to improve its performance. The first strategy, dictated by Norelem's German parent company, is focused on a closed innovation process. Indeed, the CEO points out the difficulty of implementing a business model other than that proposed by the group (I6: "With respect to business model, we are a bit constrained, since we belong to a group, and we cannot have a business model that is radically different to theirs."). The second strategy, mostly linked to the CEO's personal orientation of the French subsidiary, is related to a more open approach and is mostly achieved informally. Moreover, the CEO is aware of the fact that they have to prove to the German parent company that if they launch an OI strategy, it will be beneficial for them. The company is using exploratory OI strategies such as problem solving via experts or the participation of clients in the innovation process. But again, these initiatives are not based on a deliberate OI strategy, as the company does not have the methods to attract clients and involve them in the OI process. The motivation to be involved in OI is related to the desire to increase the speed of the innovation process (I2: "It's a strength: As soon as there is the possibility of working on a collaborative project, or open innovation, there must be more people with different profiles, ... ten brains carry more ideas than one or two brains.”).

In contrast, OI at Curana was always a direct consequence of the strategic choice to switch from an OEM strategy to a design- and innovation-driven strategy. Curana is family owned and the CEO is the owner of the company. He therefore has the complete freedom-and responsibility - to set the strategic direction of the company. This freedom allowed him to make bold decisions to change strategy (he has made strategic changes three times in <15years; see Vanhaverbeke, 2017a for details), making it impossible for fast followers to keep up with Curana in bringing new products to market. Strategic decision making and the search for major new business opportunities have always been the driver for opening up to partners that could help Curana accomplish these strategic objectives. The collective approach also implied that ideas and technology would be shared along with the benefits: The CEO keeps an eye on the fair distribution of the benefits of collaboration. For this reason, he insists on open communication, as well as open bookkeeping that will pinpoint who needs support under specific conditions, the location of the weakest link in the collaboration chain, and any emerging need for conflict resolution.

The OI strategy also concerns the expected impact of the OI projects. For Norelem, the outcomes of OI projects are related to incremental and managerial innovations. For example, an OI initiative generated the development of scheduling software to determine a better decision-making process.

Curana is a typical example of an SME that strongly benefits from OI. It has developed a high level of OI maturity. Curana deploys OI to find leading-edge technology, which it could never develop internally. Developing and commercializing novel bike parts implies that the firm has access to many technologies and skills, which an SME usually does not have. Moreover, Curana needs a variety of technologies that are often only required for one project, not on a continuous basis. As Curana works with partners from different industries, OI also brings the company into contact with ideas that are completely new to the bicycle industry. Matching different partners from different fields sparks the development of new-to-the-industry bike equipment and bike accessories. This diversity leads to unique products that enable the firm to stay ahead of competition and charge premium prices.

Concerning the financial lever, Norelem does not have a yearly budget allocated to innovation (I2: "I have no idea. There may be $x$ 
percent of the turnover yes. But I do not know its value."). The budget is not decided through a proactive process, but rather on an ad-hoc basis. Moreover, there is a lack of a cost-planning strategy that could influence the OI process.

Curana's R\&D intensity varies between 5\% and 10\% depending on the innovation projects that the company is conducting in a specific year. Projects are defined yearly and are directly derived from the firm's strategy - that is, the type of newly developed products it wants to introduce in the market. The company invests continuously in innovation, deeming it the lifeline for the company. Yet, because $\mathrm{R} \& \mathrm{D}$, new technologies, and new product development are very expensive for an SME, Curana tries to share risks and costs (but also the benefits) between partners. In this way, the firm is making use of an asset-light innovation strategy. Curana does not invest in technology whenever partners can develop it. Table 3 summarizes the major results and highlights the five levers and the factors connected to them.

\section{Discussion}

We compared Curana, a successful firm with best OI practices, and Norelem, a company that is struggling to make the transition from a closed to an OI approach. We then identified some aspects that could explain this difference between the firms. These aspects concern the OI activities performed by both firms, the combination of the five levers into a coherent OI approach, stakeholder engagement, and the characteristics of the CEOs.

By contrasting the OI activities, we find that they seem to be specific for each of the firms and for each of the five levers. The OI activities could be specific in function of the industry and the needs of the OI environment (Parida et al., 2012). For example, for the internal learning capacity, Norelem is developing creative events and using methods such as brainstorming and ideation process to capture interesting knowledge from employees and increase internal innovation. In contrast, Curana is focused on learning new skills on how to approach customers, as the new business model is focused on design. These OI activities encourage creativity and prepare Curana's employees for involvement in OI projects (Gassmann \& Enkel, 2004). However, when analyzing the OI activities of both companies for the five levers, we discover that they are deeply linked to the OI strategy.

The connection with the OI strategy is essential for a coherent view of all these OI activities. If the OI strategy is clear and accepted by all parties (Chesbrough \& Appleyard, 2007; Du Chatenier et al., 2009), it enables an efficient use and a combination of the five levers into a coherent OI approach. Indeed, in the case of Curana, the commitment to OI is a direct consequence of its strategy to develop innovative bicycle parts. OI is essential because it takes many technologies to develop new products and their costs are prohibitively high for SMEs. Working with partners in other industries also widens the scope for discovering new solutions and ideas. In contrast, Norelem is characterized by an unclear strategy regarding OI, and even more by a potential conflict between the German parent firm's innovation strategy and the subsidiary, as they have different visions of how to organize the innovation process. All of this might explain Norelem's rather opportunistic OI collaboration with its stakeholders. Previous research suggests that a successful OI strategy needs a top-down direction and a clear alignment between the parties involved in the OI process regarding business growth objectives and the desire to look for outside knowledge and technology (Chesbrough \& Crowther, 2006). To do so, Curana's CEO was actively involved in the OI strategy development and managed the network of partners minimizing conflicts and misalignments. All partners take risks and invest, but special attention is also paid to an equitable distribution of the bene- fits. Moreover, Curana built an articulated vision about why it needs to be involved in OI. The strategy of Curana leads automatically to the start of OI activities, and its OI activities have turned its audacious strategy into a formidable competitive position that it could not achieve on its own. Hence, there is a need to integrate these levers into an OI strategy. Firms that succeed in doing this excel in OI, but those that approach OI in a piecemeal way tend to struggle with OI and never realize its full potential (Vanhaverbeke, 2017a). As Chesbrough (2003) stated, OI is not a one-shot process or a temporary trend in the evolution of a firm, but rather a profound change in the firm's paradigm for handling the innovation process.

Stakeholder engagement is vital for a successful OI process (Gould, 2012; Lichtenthaler \& Lichtenthaler, 2009). When analyzing our results, we find that stakeholder engagement for both of our focal firms is dependent on several aspects. First, stakeholder engagement is deeply anchored in the OI strategy. In the case of Norelem, collaboration with stakeholders is not really planned and it is linked to one-shot demands from Norelem's customers, resulting in a rather opportunistic OI process. Consequently, Norelem suffers from not being perceived by its stakeholders as a real innovation partner, but rather as a "second-tier" supplier, very dependent on its product catalog. In contrast, Curana's collaboration with its partners is directly linked to the company's strategy. This collaboration aims to conquer the market by joint efforts and by launching entirely new products. This strong link with Curana's strategy guarantees that investments and efforts by partners are likely to pay off in new business and increased revenue.

Second, stakeholder engagement is also dependent on the types of partners involved in the OI process and on the benefits that partners may bring to the OI project. For instance, Norelem is involved in few co-development projects with partners (e.g., suppliers, clients, and universities) with different profiles and from different industries and regions. Conversely, Curana built its network of partners in an organic way, starting with a few necessary partners from the same region in 1999 and increasing to an extensive network 20years later. Stakeholder engagement is also linked to some benefits, such as the rapid introduction of internal innovation in the market or the valorization of the partners' experience and skills (Gassmann \& Enkel, 2004). For example, Norelem's collaboration with some complementary partners, such as the University of Technology of Troyes - UTT, delivers some fruitful benefits that have produced a better internal decision-making tool.

Third, stakeholder engagement could encounter some challenges, especially when working with a broad range of partners, such as the differences in innovation management style and the risk that SMEs may be hampered by the complex structure of their partners (Van de Vrande et al., 2009; Vanhaverbeke, 2017a). Indeed, the CEO of Norelem complains about the difficulty of communicating with new partners in terms of skills and knowledge when they come from different geographical regions. Building an innovation ecosystem can provide important benefits for SMEs and their stakeholders, but network management is vital for its success (Lee et al., 2010; Van de Vrande et al., 2009; Vanhaverbeke, 2017a). Consequently, network management has to be considered as a principal management task in addition to the traditional, in-house management issues of the firm (Vanhaverbeke, 2017a). To provide appropriate network management, Curana's CEO communicates daily with all the firm's departments to ensure that innovation is aligned with production, purchasing, marketing, and sales. The biggest challenge is to ensure that everyone in the company understands the innovations in the network. Therefore, Curana ensures that employees of different departments can meet with their counterparts in partnering organizations.

Also important for success are the CEO's vision and the implications for OI implementation. Generally, the CEO is involved in the 
business model innovation and the formulation of OI strategies (Vanhaverbeke, 2017a). Once the CEO recognizes OI as a strategic option, the establishment of an OI strategy is vital, as it details the flow of the innovation process (Chesbrough \& Crowther, 2006). For example, Curana's CEO is actively involved in the definition of the OI strategy, which is clearly communicated to all the parties involved. In the case of Norelem, although the CEO is personally extremely committed to developing an OI strategy, he lacks backup from the parent company and, therefore, tends to keep the decision-making process very centralized and limited, planning the innovation strategy with the R\&D manager only. Consequently, the implementation of an OI approach in Norelem is not shared by all the parties, and it remains an opportunistic process rather than a strategic one. To face these difficulties, Curana's CEO assumed personal leadership of the network, instilling his personal values such as mutual consultation, open communication, and support of the weakest link in the network. This in turn led to Curana's being recognized as a best-practice case of OI management in SMEs.

\section{Conclusion and implications}

The purpose of this study is to understand how SMEs, and more precisely small firms, collaborate with stakeholders in their transition from closed to OI. To accomplish this, we first identified factors in the OI literature that could facilitate or hamper collaboration of SMEs with their stakeholders, and then proposed a framework composed of 17 factors grouped into five levers.

Second, we applied this framework to two European industrial small firms and identified how each of these levers affects the collaboration with their respective internal and external stakeholders in an OI environment. The results show that the two companies are deploying the five levers in different ways. Curana is implementing a successful OI approach, but Norelem is having some difficulties in its transition from closed to OI. These differences are essentially related to the way the two firms are conceiving their OI strategy. Curana is employing an OI strategy that enables it to use and combine the five levers in a coherent OI strategic approach. In contrast, Norelem has serious problems in defining the OI strategy and this hampers all the firm's initiatives to switch from an opportunistic to a strategic OI process. Stakeholder engagement is also deeply influenced by the OI strategy. Norelem leads one-shot OI project initiatives with its stakeholders. In contrast, Curana starts collaboration with its stakeholders in an organic way, and each partner is chosen for its importance in the OI process and in accordance with the OI strategy. Other factors could be involved in explaining differences between the two firms: the specificity of OI activities performed by the two firms, the characteristics and visions of their CEOs, and also their cultural differences.

This study contributes to the stakeholder and OI literature. Previous literature on stakeholders identified some gaps related to the causes or antecedents of stakeholder relationships and interactions in a network (Shams, 2016). Gould (2012), in an attempt to link OI and stakeholder engagements, proposed new research avenues regarding the specific role of stakeholders in an OI environment. Our findings explore these avenues and define a framework built on five levers (knowledge, collaboration, organizational, strategic and financial) which can be further split into 17 factors influencing collaboration with stakeholders and their engagement. Compared to other studies that only detail a list of factors that could limit the collaboration with OI stakeholders (Bigliardi \& Galati, 2016; Lee et al., 2010; Van de Vrande et al., 2009), our study goes further and specifies the factors that facilitate or hinder collaboration with stakeholders in OI (see Table 3).
Our results also enrich the literature on OI in SMEs. For instance, OI literature points out that there is a lack of studies focusing on the factors hampering openness in SMEs, and on the role of external stakeholders in transforming SMEs toward OI (Hossain \& Kauranen, 2016; Vanhaverbeke, 2017a). Additionally, the OI literature has identified other gaps related to how and when to collaborate with stakeholders involved in OI (Hossain \& Kauranen, 2016). We present some new insights about the factors that foster or hinder the adoption of OI in SMEs. We also used a qualitative approach, unlike the vast majority of studies, which are focused on quantitative research (Vanhaverbeke et al., 2018; Laursen \& Salter, 2006, 2014; Fu, 2012; Spithoven et al., 2013; Drechsler \& Natter, 2012). Moreover, we also offer some new empirical insights about OI in small firms as previous research has already highlighted the difficulty of finding evidence in these contexts (van de Vrande et al., 2009; Vanhaverbeke et al., 2018; Wynarczyk et al., 2013). With this exploratory study, we give some initial managerial insights that facilitate the transition from an opportunistic to a more strategic collaboration with stakeholders involved in OI.

Our analytical framework offers a better understanding of OI management in small and medium-sized firms as it enabled us to analyze the antecedent factors that could have an impact on SME collaboration with stakeholders and the development of stakeholder engagement. We recommend it as a useful consulting tool since it shows all the factors that need to be considered by CEOs and managers when starting the OI process in SMEs. This framework was applied to analyze the two small firms, Norelem and Curana, and to compare the actions already in place and those that need to be implemented with both internal and external stakeholders if the two firms wish to open up their innovation process. For instance, one of the factors in Table 3 that is claimed to facilitate collaboration with stakeholders in an OI environment is related to the successful implementation of IP management. In both firms, IP management has an important role for OI, and they each decided to protect their innovations with patents. Yet in both cases, their main strategy was to innovate rapidly in order to keep ahead of competitors. The factors that can hinder stakeholder collaboration during an OI project are related to opportunistic behavior and budgeting and cost planning. These factors especially concern the case of Norelem, which is struggling to implement a coherent OI process. Indeed, previous research showed that opportunistic behavior could create conflicts inside an OI project (Du Chatenier et al., 2009). Moreover, the absence of an innovation budget and cost planning could hinder the success of OI projects (Du Chatenier et al., 2009; Lee et al., 2010; Van de Vrande et al., 2009). In contrast with Norelem, Curana developed a coherent OI strategy and tried to avoid the negative effect of these factors on the collaboration with its stakeholders. For example, opportunistic behavior was diminished through the intermediary of an open communication strategy and by identifying and disciplining non-loyal partners. Curana is also aware of the importance of the budget and costs related to OI projects, which are also part of its OI strategy. To optimize the OI budget, Curana worked closely with its partners and took value from their existing knowledge. This enabled Curana to acquire leading-edge technology at a relatively low cost. Cost planning for each OI project was always a major concern for Curana; the firm tried to predict the costs of working with each OI partner.

To avoid the negative consequences of these factors in an OI project, it is in the interests of companies such as Norelem to learn from Curana and build a coherent OI strategy and communicate it to its internal and external stakeholders to obtain their commitment. This strategy should explain the purpose and content that an OI model imposes on the organization in order to avoid familiar syndromes such as "not invented here" (NIH) and "not shared here" (NSH) (Bigliardi \& Galati, 2016). A clear OI strategy can also facilitate the 
planning of an innovation budget and the costs for each specific OI project.

Moreover, the mere exposure of SME managers to the OI phenomenon is not enough. They must learn to implement OI through concrete examples of OI practices provided by successful managers. However, access to these managers is not always easy, and learning time is very limited in SMEs. Indeed, examples of good OI practices in SMEs are rare, and successful managers tend to have difficulty making themselves constantly available to share their experience. Therefore, the role of supporting organizations for SMEs becomes essential for the transfer of OI practices to all SME managers. The business consultants of these organizations become key players in identifying the needs of OI in SMEs and in targeting managers who could successfully share their best OI practices.

Our findings are based on a dual case study, which limits their generalization and highlights the exploratory nature of the study. We only examined small ( $<50$ FTEs) rather than medium-sized companies, which is a further limitation as our aim was to talk about SMEs in general. At this exploratory level, it is difficult to determine the impact of the cultural context. However, future comparative studies of small firms with a different national background could form an interesting extension of the present research.

Future qualitative studies could include medium-sized firms from different countries and replicate the use of the framework in order to expand our comprehension of the implementation of OI in SMEs. In addition, research on how the cultural issues of each country might affect OI implementation in SMEs is an avenue for future research. Despite these limitations, we believe that our findings offer an interesting framework for the successful implementation of a strategic OI process that could solve the current difficulties faced by small firms willing to engage into $\mathrm{OI}$.

\section{Acknowledgments}

The authors want to express their recognition for valuable feedback from two of the guest editors, Riad Shams and Demetris Vrontis for the paper improvement, as well as for constructive comments from two anonymous reviewers during the manuscript evolution.

We thank also both CEOs - Russel Kelly-Norelem and Dirk VensCurana- for their help and support in the realization of the empirical part.

In addition, we thank particularly both, Susan Leclercq and Elsa Peterson, for their help in proofreading the article.

\section{Funding}

This research did not receive any specific grant from funding agencies in the public, commercial, or not-for-profit sectors.

\section{Declaration of competing interest}

The authors have no competing interest to declare.

Appendix A.

Table 1

Proposition for a framework for open innovation organizational intention at Norelem and Curana.

\begin{tabular}{|c|c|c|}
\hline Levers & $\begin{array}{l}\text { Factors re- } \\
\text { lated to the } \\
\text { levers }\end{array}$ & References \\
\hline \multirow[t]{3}{*}{$\begin{array}{l}\text { Knowl- } \\
\text { edge } \\
\text { lever }\end{array}$} & $\begin{array}{l}\text { Internal learn- } \\
\text { ing capacity }\end{array}$ & $\begin{array}{l}\text { Bontis et al. (2002); Vanhaverbeke (2017a); } \\
\text { Davenport and Prusak (1997); Gassmann and } \\
\text { Enkel (2004) }\end{array}$ \\
\hline & $\begin{array}{l}\text { Absorptive ca- } \\
\text { pacity }\end{array}$ & $\begin{array}{l}\text { Cohen and Levinthal (2000); Davenport and } \\
\text { Klahr (1998); Von Krogh (1998) }\end{array}$ \\
\hline & $\begin{array}{l}\text { Intellectual } \\
\text { property man- } \\
\text { agement is- } \\
\text { sues }\end{array}$ & $\begin{array}{l}\text { Verbano et al. (2015); Vanhaverbeke (2017a); } \\
\text { Kalanje (2006); Chesbrough (2003); Van de } \\
\text { Vrande et al. (2009); Lee et al. (2010); McEvily } \\
\text { et al. (2004); Vanhaverbeke (2006); Gassmann } \\
\text { et al. (2010) }\end{array}$ \\
\hline \multirow[t]{4}{*}{$\begin{array}{l}\text { Collabo- } \\
\text { ration } \\
\text { lever }\end{array}$} & $\begin{array}{l}\text { Issues in find- } \\
\text { ing the right } \\
\text { partners in- } \\
\text { cluding cus- } \\
\text { tomers }\end{array}$ & $\begin{array}{l}\text { Bigliardi and Galati (2016); Enkel et al. (2009); } \\
\text { Van de Vrande et al. (2009); Kaufmann and } \\
\text { Tödtling (2001); Noland and Phillips (2010); } \\
\text { Gould (2012); Geiger et al. (2011) }\end{array}$ \\
\hline & $\begin{array}{l}\text { Frequency } \\
\text { and types of } \\
\text { relationships } \\
\text { with partners }\end{array}$ & $\begin{array}{l}\text { Elfring and Hulsink (2003); Vanhaverbeke } \\
\text { (2017a); Vyakarnam et al. (1997); Spence et al. } \\
\text { (2003) }\end{array}$ \\
\hline & $\begin{array}{l}\text { Cultural dif- } \\
\text { ferences with } \\
\text { partners }\end{array}$ & $\begin{array}{l}\text { Van de Vrande et al. (2009); Vanhaverbeke } \\
\text { (2017a); Du Chatenier et al. (2009); Yitmen } \\
\text { (2015) }\end{array}$ \\
\hline & $\begin{array}{l}\text { Opportunistic } \\
\text { behavior of } \\
\text { collaboration } \\
\text { partners }\end{array}$ & $\begin{array}{l}\text { Cassiman and Veugelers (2002); McEvily et al. } \\
\text { (2004); Henkel et al. (2014); De Faria and Sofka } \\
\text { (2010) }\end{array}$ \\
\hline \multirow{4}{*}{$\begin{array}{l}\text { Organi- } \\
\text { za- } \\
\text { tional } \\
\text { lever }\end{array}$} & $\begin{array}{l}\text { Organiza- } \\
\text { tional struc- } \\
\text { ture }\end{array}$ & $\begin{array}{l}\text { Van de Vrande et al. (2009); Vanhaverbeke } \\
\text { (2017a); Bigliardi and Galati (2016) }\end{array}$ \\
\hline & $\begin{array}{l}\text { Managerial } \\
\text { skills needed } \\
\text { to establish an } \\
\text { effective col- } \\
\text { laboration }\end{array}$ & $\begin{array}{l}\text { Bigliardi and Galati (2016); Van de Vrande et al. } \\
\text { (2009); Teirlinck and Spithoven (2013); } \\
\text { Verbano et al. (2015); Ackermann and Eden } \\
\text { (2011); Greenwood (2007); Verbano et al. } \\
\text { (2015) }\end{array}$ \\
\hline & $\begin{array}{l}\text { Culture issues: } \\
\text { specifics and } \\
\text { resistance in- } \\
\text { side the firm }\end{array}$ & $\begin{array}{l}\text { Van de Vrande et al. (2009); Vanhaverbeke } \\
\text { (2017a); Bigliardi and Galati (2016); Greenwood } \\
\text { (2007) }\end{array}$ \\
\hline & $\begin{array}{l}\text { Administra- } \\
\text { tive and legal } \\
\text { burdens }\end{array}$ & $\begin{array}{l}\text { Van de Vrande et al. (2009); Bigliardi and Galati } \\
\text { (2016); Vanhaverbeke (2017a) }\end{array}$ \\
\hline \multirow[t]{4}{*}{$\begin{array}{l}\text { Strategic } \\
\text { lever }\end{array}$} & $\begin{array}{l}\text { Strategy in } \\
\text { managing } \\
\text { open innova- } \\
\text { tion }\end{array}$ & $\begin{array}{l}\text { Van de Vrande et al. (2009); Laursen and Salter } \\
\text { (2006); Parida et al. (2012); Vanhaverbeke } \\
\text { (2017a); Ahn et al. (2017); Du Chatenier et al. } \\
\text { (2009); Chesbrough and Appleyard (2007); } \\
\text { Keupp and Gassmann (2009); Chesbrough and } \\
\text { Crowther (2006) }\end{array}$ \\
\hline & $\begin{array}{l}\text { Grant a tech- } \\
\text { nology to oth- } \\
\text { ers without a } \\
\text { comprehen- } \\
\text { sive under- } \\
\text { standing of its } \\
\text { potential }\end{array}$ & $\begin{array}{l}\text { Bigliardi and Galati (2016); Geiger et al. (2011); } \\
\text { Davenport and Prusak (1997) }\end{array}$ \\
\hline & $\begin{array}{l}\text { Motivations } \\
\text { for OI process }\end{array}$ & $\begin{array}{l}\text { Van de Vrande et al. (2009); Lee et al. (2010); } \\
\text { Vanhaverbeke (2017a); Du Chatenier et al. } \\
\text { (2009) }\end{array}$ \\
\hline & $\begin{array}{l}\text { Impact ex- } \\
\text { pected for OI } \\
\text { projects }\end{array}$ & Hughes et al., 2007; Du Chatenier et al. (2009) \\
\hline $\begin{array}{l}\text { Financial } \\
\text { lever }\end{array}$ & $\begin{array}{l}\text { Economic/fi- } \\
\text { nancial issues } \\
\text { process } \\
\text { Costs higher } \\
\text { than planned }\end{array}$ & $\begin{array}{l}\text { Van de Vrande et al. (2009); Teirlinck and } \\
\text { Spithoven (2013); Du Chatenier et al. (2009); } \\
\text { Lasagni (2012); Lee et al. (2009) } \\
\text { Teirlinck and Spithoven (2013), Van de Vrande } \\
\text { et al. (2009); Du Chatenier et al. (2009); } \\
\text { Christensen et al. (2005); Enkel et al. (2009) }\end{array}$ \\
\hline
\end{tabular}

\section{Appendix B.}

Table 2 Internal and external stakeholders involved in the OI process for Norelem and $\mathrm{Cu}$ rana. 


\begin{tabular}{|c|c|c|c|c|}
\hline & Function & Code & Date & $\begin{array}{l}\text { Dura- } \\
\text { tion }\end{array}$ \\
\hline \multirow[t]{11}{*}{ Norelem } & Communication officer & I1 & $21 / 04 / 2017$ & $29 \mathrm{~min}$ \\
\hline & $\begin{array}{l}\text { Quality and production man- } \\
\text { ager }\end{array}$ & I2 & $21 / 04 / 2017$ & $27 \mathrm{~min}$ \\
\hline & R\&D manager & I3 & $12 / 04 / 2017$ & $1 \mathrm{~h}$ \\
\hline & $\begin{array}{l}\text { Factory and cross-cutting pro- } \\
\text { ject manager }\end{array}$ & I4 & $21 / 04 / 2017$ & $41 \mathrm{~min}$ \\
\hline & Purchase and supply manager & I5 & $12 / 04 / 2017$ & $46 \mathrm{~min}$ \\
\hline & $\mathrm{CEO} /$ commercial manager & I6 & $\begin{array}{l}(11 / 2016 \\
02 / 2017) \\
8 / 02 / 2018\end{array}$ & $53 \mathrm{~min}$ \\
\hline & $\begin{array}{l}\text { Regional technical university in- } \\
\text { volved in development of soft- } \\
\text { ware for better decision-making }\end{array}$ & E1 & $13 / 02 / 2018$ & $28 \mathrm{~min}$ \\
\hline & $\begin{array}{l}\text { French MNE involved in a door } \\
\text { handle project - car industry } \\
\text { leader }\end{array}$ & E2 & $28 / 11 / 2017$ & $40 \mathrm{~min}$ \\
\hline & $\begin{array}{l}\text { Regional SME involved in the } \\
\text { development of pricing opti- } \\
\text { mization tool }\end{array}$ & E3 & $14 / 12 / 2017$ & $53 \mathrm{~min}$ \\
\hline & $\begin{array}{l}\text { French MNE involved in a } \\
\text { molding project - tire industry } \\
\text { leader }\end{array}$ & E4 & $22 / 11 / 2017$ & $1 \mathrm{~h}$ \\
\hline & $\begin{array}{l}\text { Regional SME involved in a } \\
\text { mechatronics project }\end{array}$ & E5 & 9/11/2017 & $45 \mathrm{~min}$ \\
\hline \multirow[t]{9}{*}{ Curana } & CEO & $\mathrm{I} 1$ & $\begin{array}{l}2009 ; 2014 \\
06 / 09 / 2018\end{array}$ & $\begin{array}{l}2 \times 90 \\
\min \\
45 \mathrm{~min}\end{array}$ \\
\hline & Production engineer & $\mathrm{I} 2$ & 2010 & $45 \mathrm{~min}$ \\
\hline & Designer 1 & I3 & 2010 & $45 \mathrm{~min}$ \\
\hline & Designer 2 & I4 & 2010 & $45 \mathrm{~min}$ \\
\hline & Polymer extruder (designer) & E1 & $\begin{array}{l}2010 \\
06 / 09 / 2018\end{array}$ & $\begin{array}{l}45 \mathrm{~min} \\
1 \mathrm{~h}\end{array}$ \\
\hline & Technical center & E2 & 2010 & $30 \mathrm{~min}$ \\
\hline & $\begin{array}{l}\text { Client } 1 \text { (belonging to same } \\
\text { group) }\end{array}$ & E3 & 2010 & $60 \mathrm{~min}$ \\
\hline & $\begin{array}{l}\text { Client } 2 \text { (belonging to same } \\
\text { group) }\end{array}$ & E4 & 2010 & $60 \mathrm{~min}$ \\
\hline & Lock manufacturer & E5 & 2014 & $30 \mathrm{~min}$ \\
\hline
\end{tabular}

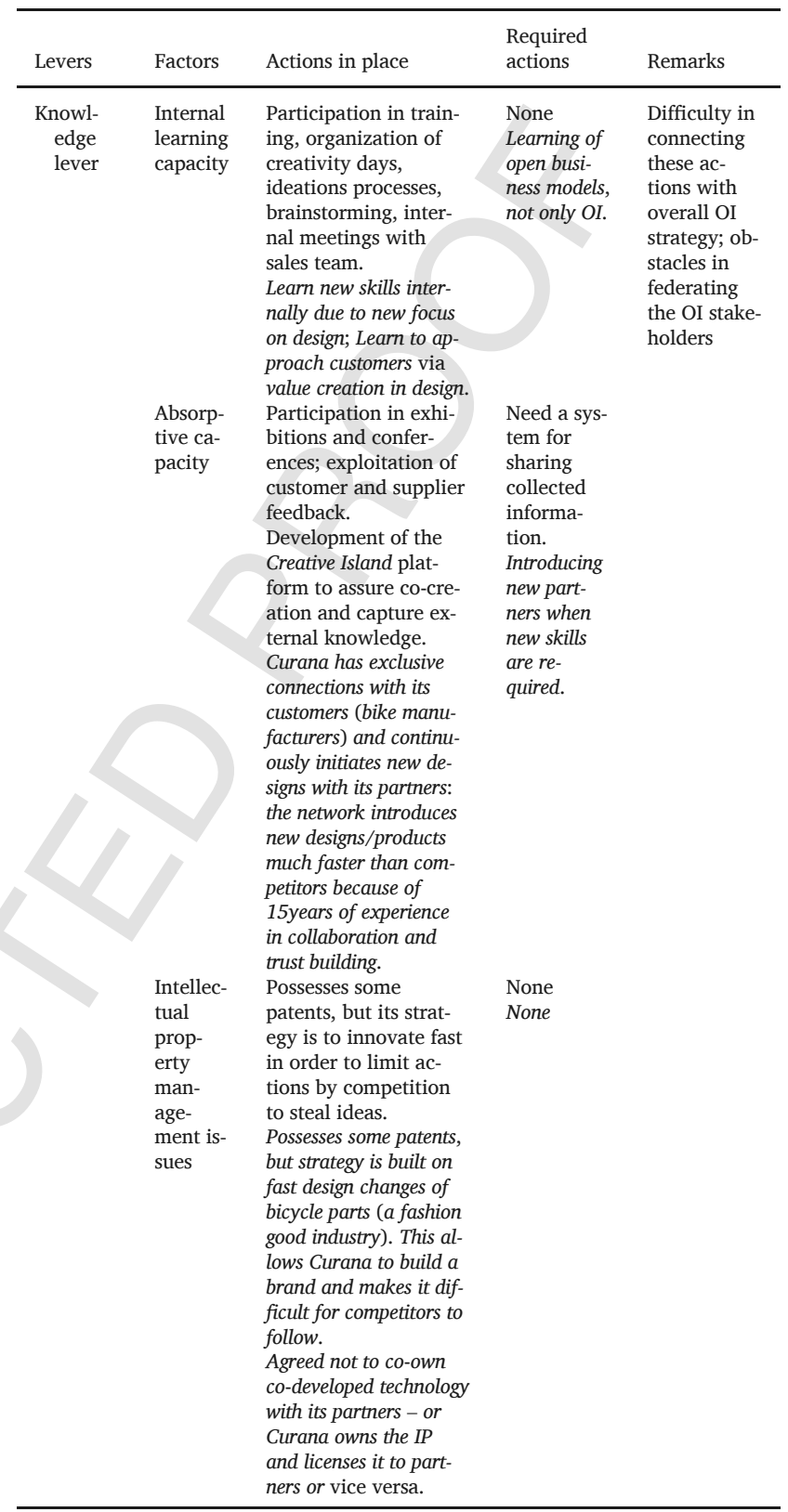

Table 3

Summary of results (Curana's results in italics).

Appendix C. 


\begin{tabular}{|c|c|c|c|c|}
\hline $\begin{array}{l}\text { Collabo- } \\
\text { ration } \\
\text { lever }\end{array}$ & $\begin{array}{l}\text { Fre- } \\
\text { quency } \\
\text { and } \\
\text { types of } \\
\text { rela- } \\
\text { tion- } \\
\text { ships } \\
\text { with the } \\
\text { OI } \\
\text { stake- } \\
\text { holders }\end{array}$ & $\begin{array}{l}\text { Norelem is collaborat- } \\
\text { ing with stakeholders } \\
\text { such as the lead users, } \\
\text { suppliers, and univer- } \\
\text { sities. It is involved in } \\
\text { research programs } \\
\text { with the local univer- } \\
\text { sity (UTT) and also } \\
\text { collaborates with its } \\
\text { employees. } \\
\text { Curana started with } \\
\text { only a few partners in } \\
1999 \text { when it began its } \\
\text { first OI initiative. The } \\
\text { first product took three } \\
\text { years to develop and } \\
\text { was a radical innova- } \\
\text { tion and a major suc- } \\
\text { cess. Now the firm is } \\
\text { recognized as a design } \\
\text { leader and for its OI- } \\
\text { network. It has to select } \\
\text { diligently among differ- } \\
\text { ent potential partners. }\end{array}$ & $\begin{array}{l}\text { Need for } \\
\text { collabora- } \\
\text { tions with } \\
\text { weak-tie } \\
\text { stakehold- } \\
\text { ers is im- } \\
\text { portant for } \\
\text { radical in- } \\
\text { novation } \\
\text { Engaging in } \\
\text { new types of } \\
\text { projects } \\
\text { does not al- } \\
\text { ways work } \\
\text { with the ex- } \\
\text { isting part- } \\
\text { ners (new } \\
\text { partner } \\
\text { search) and } \\
\text { requires } \\
\text { new ways of } \\
\text { collabora- } \\
\text { tion and } \\
\text { value shar- } \\
\text { ing. Un- } \\
\text { learning is } \\
\text { important. } \\
\text { Need for } \\
\text { better com- } \\
\text { munication } \\
\text { with OI } \\
\text { stakehold- } \\
\text { ers with } \\
\text { different } \\
\text { profiles } \\
\text { and cul- } \\
\text { tures } \\
\text { The interna- } \\
\text { tionaliza- } \\
\text { tion of Cu- } \\
\text { rana led to } \\
\text { more inter- } \\
\text { national } \\
\text { collabora- } \\
\text { tion with a } \\
\text { more varied } \\
\text { set of part- } \\
\text { ners, which } \\
\text { is more dif- } \\
\text { ficult to un- } \\
\text { derstand } \\
\text { and man- } \\
\text { age. } \\
\end{array}$ & $\begin{array}{l}\text { Collabora- } \\
\text { tion is more } \\
\text { opportunis- } \\
\text { tic and lim- } \\
\text { ited. Per- } \\
\text { ceived by } \\
\text { stakeholders } \\
\text { as trustful, } \\
\text { but also as a } \\
\text { 'second-tier' } \\
\text { supplier that } \\
\text { is very de- } \\
\text { pendent on } \\
\text { its product } \\
\text { catalog. } \\
\text { Its reputation } \\
\text { and visibility } \\
\text { make it easy } \\
\text { for Curana } \\
\text { to find part- } \\
\text { ners. The se- } \\
\text { lection of } \\
\text { partners re- } \\
\text { sults from the } \\
\text { projects the } \\
\text { company } \\
\text { wants to de- } \\
\text { velop. }\end{array}$ \\
\hline
\end{tabular}

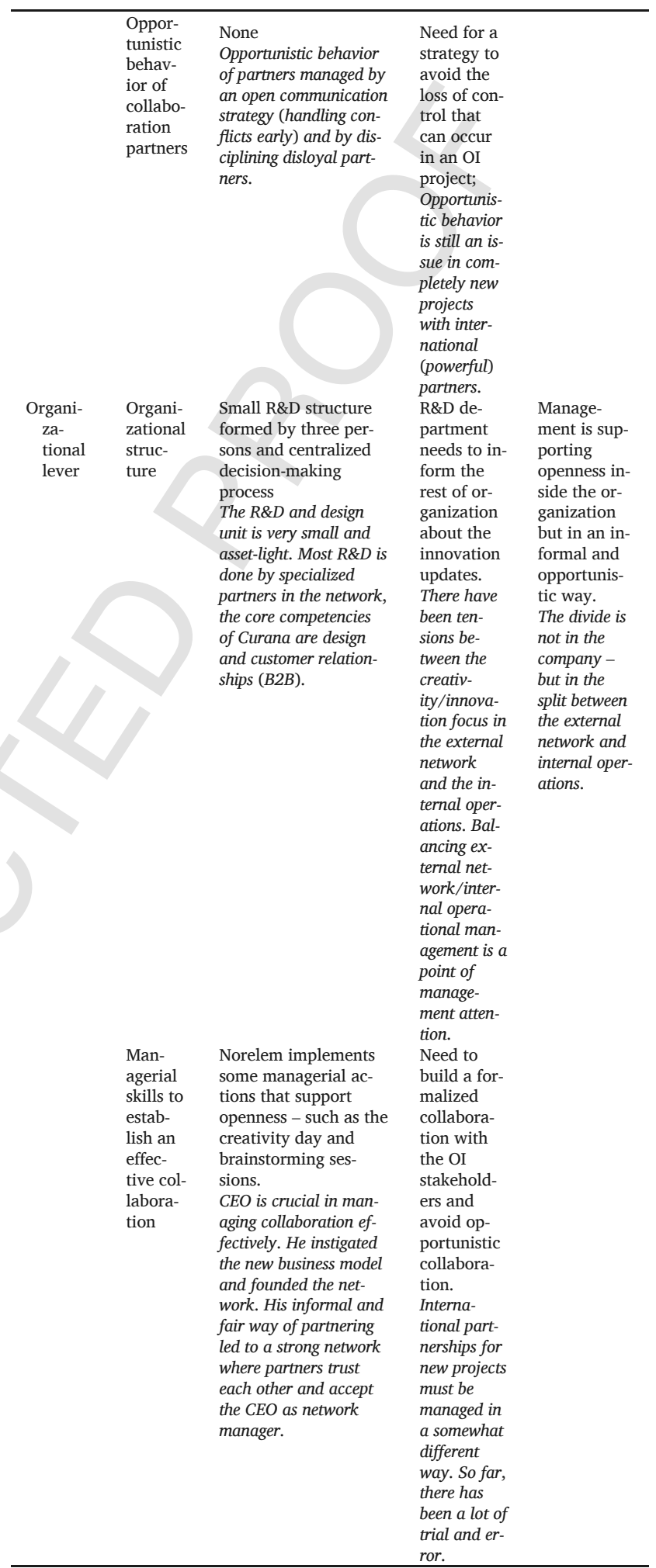




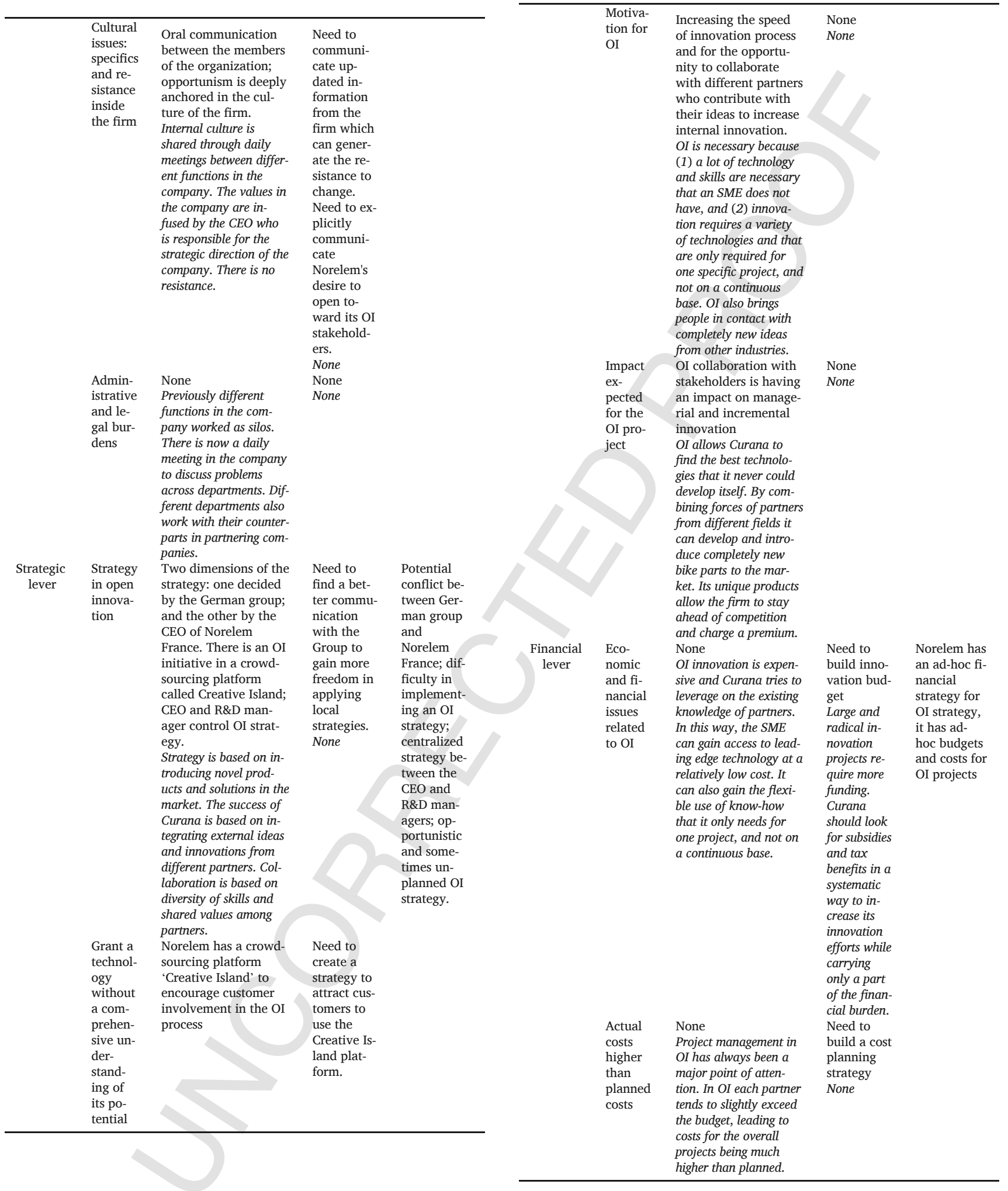

\section{References}

Ackermann, F., Eden, C., 2011. Strategic management of stakeholders: Theory and practice. Long Range Planning 44 (3), 179-196. 
Ahn, J., Minshall, T., Mortara, L., 2017. Understanding the human side of openness: The fit between open innovation modes and CEO characteristics. R\&D Management 47 (5), 727-740.

Ahn, J.M., Minshall, T.H.W., Mortara, L., 2015. Open innovation: An approach for enhancing performance in innovative SMEs. Journal of Innovation Management $3,33-54$.

Antonacopoulou, E.P., Meric, J., 2005. From power to knowledge relationships: Stakeholder interactions as learning partnerships. In: Bonnafous_Boucher, M., Pesqueux, Y. (Eds.), Stakeholder theory: A European perspective. Palgrave Macmillan, New York, pp. 125-147.

Asakawa, K., Nakamura, H., Sawada, N., 2010. Firms' open innovation policies, laboratories' external collaborations, and laboratories' R\&D performance. R\&D Management 40 (2), 109-123.

Ayuso, S., Rodriguez, M., Ricart, J.-E., 2006. Responsible competitiveness at the "micro" level of the firm: Using stakeholder dialogue as a source for new ideas: A dynamic capability underlying sustainable innovation. Corporate Governance 6 (4), 475-490.

Ballejos, L.C., Montagna, J.M., 2008. Method for stakeholder identification in interorganizational environments. Requirements Engineering 13 (4), 281-297.

Beringer, C., Jonas, D., Kock, A., 2013. Behavior of internal stakeholders in project portfolio management and its impact on success. International Journal of Project Management 31 (6), 830-846.

Berthinier-Poncet, A., Grama, S., Saidi, S., 2017. Convergences ou divergences de vues? L'effet sur l'innovation des différences de perception entre gouvernance et entreprises d'un technopôle. Management International 21 (2), 32-46.

Bianchi, M., Cavaliere, A., Chiaroni, D., Frattini, F., Chiesa, V., 2011. Organisational modes for open innovation in the bio-pharmaceutical industry: An exploratory analysis. Technovation 31 (1), 22-33.

Bigliardi, B., Galati, F., 2016. Which factors hinder the adoption of open innovation in SMEs?. Technology Analysis \& Strategic Management 28 (8), 869-885.

Bontis, N., Crossan, M., Hulland, J., 2002. Managing an organizational learning system by aligning stocks and flows. Journal of Management Studies 39 (4), 437-469.

Brunswicker, S., Vanhaverbeke, W., 2011. Beyond open innovation in large enterprises: How do small and medium-sized enterprises (SMEs) open up to external innovation sources?, (Available at SSRN 1925185).

Brunswicker, S., Vanhaverbeke, W., 2015. Open innovation in small and medium sized enterprises (SMEs): External knowledge sourcing strategies and internal organizational facilitators. Journal of Small Business Management 53 (4), 1241-12663.

Cassiman, B., Veugelers, R., 2002. R\&D cooperation and spillovers: Some empirical evidence from Belgium. American Economic Review 92 (4), 1169-1184.

Chesbrough, H., Crowther, A.K., 2006. Beyond high tech: Early adopters of open innovation in other industries. R\&D Management 36 (3), 229-236.

Chesbrough, H., Prencipe, A., 2008. Networks of innovation and modularity: A dynamic perspective. International Journal of Technology Management 42 (4), 414-425.

Chesbrough, H., Schwartz, K., 2007. Innovating business models with co-development partnerships. Research-Technology Management 50 (1), 55-59.

Chesbrough, H.W., 2003. The era of open manufacturing. Sloan Management Review 44 (3), 35-41.

Chesbrough, H.W., Appleyard, M.M., 2007. Open innovation and strategy. California Management Review 50 (1), 57-76.

Chesbrough, H.W., Vanhaverbeke, W., West, J., 2006. Open innovation: Researching a new paradigm. Oxford University Press, Oxford.

Christensen, J.F., Olesen, M.H., Kjaer, J.S., 2005. The industrial dynamics of open innovation: Evidence from the transformation of consumer electronics. Research Policy 34 (10), (1553-1549).

Cohen, W.M., Levinthal, D.A., 2000. Absorptive capacity: A new perspective on learning and innovation. In: Strategic learning in a knowledge economy. pp. $39-67$.

Davenport, T.H., Klahr, P., 1998. Managing customer support knowledge. California Management Review 40 (3), 195-208.

Davenport, T.H., Prusak, L., 1997. Information ecology: Mastering the information and knowledge environment. Oxford University Press on Demand, New York.

De Faria, P., Sofka, W., 2010. Knowledge protection strategies of multinational firms-a cross country comparison. Research Policy 39 (6), 699-709.

De Toni, A., Nassimbeni, G., 2003. Small and medium district enterprises and the new product development challenge. International Journal of Operations and Production Management 23 (6), 678-697.

Drechsler, W., Natter, M., 2012. Understanding a firm's openness decisions in innovation. Journal of Business Research 65 (3), 438-445.

Du Chatenier, E., Verstegen, J.A.A.M., Biemans, H.J.A., Mulder, M., Omta, O., 2009. The challenges of collaborative knowledge creation in open innovation teams. Human Resource Development Review 8 (3), 350-381.

Durst, S., Stähle, P., 2013. Success factors of open innovation - a literature review. International Journal of Business Research and Management 4 (4), 111-131.

Eisenhardt, K.M., Graebner, M.E., 2007. Theory building from cases: Opportunities and challenges. Academy of Management Journal 50 (1), 25-32.

Elfring, T., Hulsink, W., 2003. Networks in entrepreneurship: The case of high-technology firms. Small Business Economics 21 (4), 409-422.

Enkel, E., Gassmann, O., Chesbrough, H., 2009. Open R\&D and open innovation: Exploring the phenomenon. R\&D Management 39 (4), 311-316.

Freeman, R., 1984. Strategic management: A Stakeholder's approach. Pitman, Boston, MA.

Freeman, R., McVea, J., 2001. A stakeholder approach to strategic management. In: Hitt, M., Freeman, R., Harrison, J. (Eds.), The Blackwell Handbook of Strategic Management. Blackwell Business, Oxford, pp. 189-207.

Freeman, R.E., Wicks, A.C., Parmar, B., 2004. Stakeholder theory and "the corporate objective revisited". Organization Science 15 (3), 364-369.
$\mathrm{Fu}, \mathrm{X}$., 2012. How does openness affect the importance of incentives for innovation?. Research Policy 41 (3), 512-523.

Gao, S.S., Zhang, J.J., 2001. A comparative study of stakeholder engagement approaches in social auditing. In: Perspectives on corporate citizenship. pp. 239-255.

Garud, R., Nayyar, P.R., 1994. Transformative capacity: Continual structuring by intertemporal technology transfer. Strategic Management Journal 15 (5), 365-385. assmann, O., Enkel, E., 2004. Towards a theory of open innovation: Three core process archetypes. In: Maskell, P., Laursen, K., Özcan, S. (Eds.), Proceedings of the R\&D Management Conference, Lisbon Portugal, 6-9 July. Copenhagen Business School, Copenhagen, pp. 1-18.

Gassmann, O., Enkel, E., Chesbrough, H., 2010. The future of open innovation. R\&D Management 40 (3), 213-221.

Geiger, D., Rosemann, M., Fielt, E., 2011. Crowdsourcing information systems: A systems theory perspective. In: Proceedings of the 22nd Australasian Conference on Information Systems (ACIS 2011).

Giannopoulou, E., Yström, A., Ollila, S, Fredberg T Elmquist, M., 2010. Implications of openness: A study into (all) the growing literature on open innovation. Journal of Technology Management \& Innovation 5 (3), 162-180

Gould, R.W., 2012. Open innovation and stakeholder engagement. Journal of Technology Management \& Innovation 7 (3), 1-11.

Grando, A., Belvedere, V., 2006. District's manufacturing performances: A comparison among large, small-to-medium sized and district enterprises. International Journal of Production Economics 104 (1), 85-99.

Greenwood, M., 2007. Stakeholder engagement: Beyond the myth of corporate responsibility. Journal of Business Ethics 74 (4), 315-327.

Gulati, R., 1999. Network location and learning: The influence of network resources and firm capabilities on alliance formation. Strategic Management Journal 20 (5), 397-420.

Harrison, J.S., St. John, C.H., 1996. Managing and partnering with external stakeholders. Academy of Management Perspectives 10 (2), 46-60.

Henkel, J., Shoberl, S., Alexy, O., 2014. The emergence of openness: How and why firms adopt selective revealing in open innovation. Research Policy 43 (5), 879-890.

Hossain, M., Kauranen, I., 2016. Open innovation in SMEs: A systematic literature review. Journal of Strategy and Management 9 (1), 58-73.

Hughes, M., Ireland, R.D., Morgan, R.E., 2007. Stimulating dynamic value: Social capital and business incubation as a pathway to competitive success. Long Range Planning 40 (2), 154-177.

Huizingh, E.K.R.E., 2011. Open innovation: State of the art and future perspective. Technovation 31 (1), 2-9.

Kalanje, C.M., 2006. Role of intellectual property in innovation and new product development. In: World Intellectual Property Organization.

Kathan, W., Matzler, K., Füller, J., Hautz, J., Hutter, K., 2014. Open innovation in SMEs: A case study of a regional open innovation platform. Problems and Perspectives in Management 12 (1), 161-171.

Katsoulakos, T., Katsoulacos, Y., 2007. Integrating corporate responsibility principles and stakeholder approaches into mainstream strategy: A stakeholder-oriented and integrative strategic management framework. Corporate Governance: The International Journal of Business in Society 7 (4), 355-369.

Kaufmann, A., Tödtling, F., 2001. Science-industry interaction in the process of innovation: The importance of boundary-crossing between systems. Research Policy 30 (5), 791-804

Keupp, M.M., Gassmann, O., 2009. Determinants and archetype users of open innovation. R\&D Management 39 (4), 331-341.

Klijn, E.-H., Eshuis, J., Braun, E., 2012. The influence of stakeholder involvement on the effectiveness of place branding. Public Management Review 14 (4), 499-519.

Knudsen, M.P., Mortensen, T.B., 2011. Some immediate-but negative-effects of openness on product development performance. Technovation 31 (1), 54-64.

Kogut, B., 2000. The network as knowledge: Generative rules and the emergence of structure. Strategic Management Journal 21 (3), 405-425.

Lasagni, A., 2012. How can external relationships enhance innovation in SMEs? New evidence for Europe. Journal of Small Business Management 50 (2), 310-339.

Laursen, K., Salter, A., 2006. Open for innovation: The role of openness in explaining innovation performance among UK manufacturing firms. Strategic Management Journal 27 (2), 131-150.

Lee, S., Park, G., Yoon, B., Park, J., 2010. Open innovation in SMEs-An intermediated network model. Research Policy 39 (2), 290-300.

Lee, Y.G., Park, S.H., Song, Y.I., 2009. Which is better for a firm's financial performance: An externally oriented innovation strategy? An empirical study on Korean SMEs. Asian Journal of Technology 17 (1), 57-73.

Lichtenthaler, U., 2008. Open innovation in practice: An analysis of strategic approaches to technology transactions. IEEE Transactions on Engineering Management 55 (1), 148-157.

Lichtenthaler, U., 2011. Open innovation: Past research, current debates, and future directions. Academy of Management Perspectives 25 (1), 75-93.

Lichtenthaler, U., Lichtenthaler, E., 2009. A capability-based framework for open innovation: Complementing absorptive capacity. Journal of Management Studies 46 (8), 1315-1338.

Markovic, S., Bagherzadeh, M., 2018. How does breadth of external stakeholder cocreation influence innovation performance? Analyzing the mediating roles of knowledge sharing and product innovation. Journal of Business Research 88, 173-186.

McEvily, S.K., Eisenhardt, K.M., Prescott, J.E., 2004. The global acquisition, leverage, and protection of technological competencies. Strategic Management Journal 25 (8-9), 713-722.

Miles, M.P., Munilla, L.S., Darroch, J., 2006. The role of strategic conversations with stakeholders in the formation of corporate social responsibility strategy. Journal of Business Ethics 69 (2), 195-205. 
Mitchell, R.K., Agle, B., Wood, D., 1997. Toward a theory of stakeholder identification and salience: Defining the principle of who and what really counts. Academy of Management Review 22 (4), 853-886.

Neubaum, D.O., Dibrell, C., Craig, J.B., 2012. Balancing natural environmental concerns of internal and external stakeholders in family and non-family businesses. Journal of Family Business Strategy 3 (1), 28-37.

Nilsson, P., Fagerström, B., 2006. Managing stakeholder requirements in a product modelling system. Computers in Industry 57 (2), 167-177.

Noland, J., Phillips, R., 2010. Stakeholder engagement, discourse ethics and strategic management. International Journal of Management Reviews 12 (1), 39-49.

Nonaka, I., Takeuchi, H., 2007. The knowledge-creating company. Harvard Business Review 85 (7-8), 162-171.

Parida, V., Westerberg, M., Frishammar, J., 2012. Inbound open innovation activities in high-tech SMEs: The impact on innovation performance. Journal of Small Business Management 50 (2), 283-309.

Parmar, B.L., Freeman, R.E., Harrison, J.S., Wicks, A.C., Purnell, L., De Colle, S. 2010. Stakeholder theory: The state of the art. The Academy of Management Annals 4 (1), 403-445.

Plaza-Úbeda, J.A., Burgos-Jiménez, J., Vazquez, D.A., Liston-Heyes, C., 2009. The 'win-win' paradigm and stakeholder integration. Business Strategy and the Environment 18 (8), 487-499.

Rahman, H., Ramos, I., 2010. Open innovation in SMEs: From close boundaries to networked paradigm. Issues in Informing Science and Information Technology 7 , 471-487.

Roloff, J., 2008. Learning from multi-stakeholder networks: Issue-focussed stakeholder management. Journal of Business Ethics 82 (1), 233-250.

Shams, S.M.R., 2016. Capacity building for sustained competitive advantage: A conceptual framework. Marketing Intelligence \& Planning 34 (5), 671-691.

Sharma, S., 2005. Through the lens of managerial interpretations: Stakeholder engagement, organizational knowledge and innovation. In: Sharma, S., AragónCorrea, J.A. (Eds.), Environmental Strategy and Competitive Advantage. Edward Elgar Academic Publishing, Northampton, pp. 49-70.

Spence, L.J., Schmidpeter, R., Habisch, A., 2003. Assessing social capital: Small and medium sized enterprises in Germany and the UK. Journal of Business Ethics 47 (1), 17-29.

Spithoven, A., Vanhaverbeke, W., Roijakkers, N., 2013. Open innovation practices in SMEs and large enterprises. Small Business Economics 41 (3), 537-562.

Svendsen, A., 1998. The stakeholder strategy: Profiting from collaborative business relationships. Berrett-Koehler Publishers, Inc, San Francisco.

Teirlinck, P., Spithoven, A., 2013. Research collaboration and R\&D outsourcing: Different R\&D personnel requirements in SMEs. Technovation 33 (4-5), 142-153.

Usman, M., Roijakkers, N., Vanhaverbeke, W., Frattini, F., 2018. A systematic review of the literature on open innovation in SMEs. In: Vanhaverbeke, W., Frattini, F. Roijakkers, N., Usman, M. (Eds.), Researching open innovation in SMEs. World Scientific Publishing Co. Pte. Ltd, pp. 3-35.

Van de Vrande, V., De Jong, J., Vanhaverbeke, W., De Rochemont, M., 2009. Open nnovation in SMEs: Trends, motives and management challenges. Technovation 29 (6-7), 423-437.

Vanhaverbeke, W., 2006. The inter-organizational context of open innovation. In: Chesbrough, H.W., Vanhaverbeke, W., West, J. (Eds.), Open innovation: Researching a new paradigm. Oxford University Press, Oxford, pp. 205-219.

Vanhaverbeke, W., 2017. Managing open innovation in SMEs, Cambridge University Press, Cambridge.

Vanhaverbeke, W., 2017. Curana: Managing open innovation for growth in SME (A), (Ivey case 9B17M139).

Vanhaverbeke, W., Cloodt, M., 2006. Open innovation in value networks. In: Open innovation: Researching a new paradigm. pp. 258-281.

Vanhaverbeke, W., Frattini, F., Roijakkers, N., Usman, M., 2018. Researching open innovation in SMEs. World Scientific Publishing Co. Pte. Ltd..

Verbano, C., Crema, M., Venturini, K., 2015. The identification and characterization of open innovation profiles in Italian small and medium-sized enterprises. Journal of Small Business Management 53 (4), 1052-1075.

Von Krogh, G., 1998. Care in knowledge creation. California Management Review 40 (3), 133-153.

Vyakarnam, S., Bailey, A., Meyers, A., Burnett, D., 1997. Towards an understanding of ethical behavior in small firms. Journal of Business Ethics 16 (15), 1625-1636.

Waddock, S., 2001. Integrity and mindfulness: Foundations of corporate citizenship. In: Andriof, J., Mclntosh, M. (Eds.), Perspective on corporate citizenship. Greenleaf Publishing Limited, Sheffield, pp. 26-38.

Wynarczyk, P., Piperopoulos, P., McAdam, M., 2013. Open innovation in small and medium-sized enterprises: An overview. International Small Business Journal 31 (3), 240-255.

Yin, R.K., Case study research : Design and methods (3rd ed.), 2003, Sage Publica-
Y. tions; Thousand Oaks, CA.

Yin, R.K., 2016. Qualitative research from start to finish, 2nd ed. The Guilford Press, N.K.

Yitmen, I., 2015. The influence of cross-cultural communication on stakeholder management process in international construction projects: Turkish stakeholders perspective. International Journal of Civil Engineering 13 (2), 179-190.

Zadek, S., 2001. Partnership alchemy: Engagement, innovation and governance. In: Andriof, J., McIntosh, M. (Eds.), Perspectives on corporate citizenship. Greenleaf Publishing Limited, Sheffield, pp. 200-214.

Zollo, M., Winter, S.G., 2002. Deliberate learning and the evolution of dynamic capabilities. Organization Science 13 (3), 339-351.

Sana Saidi holds a PhD in Management Sciences from the University of Toulouse 1 since 2011. She is actually an assistant professor in Finance at SCBS since 2013. Her main fields of research lie at the fron- tier between accounting and entrepreneurship. They focus on the sociocultural and politico-institutional practices of audit firms and accountants, entrepreneurial intention, the entrepreneurial motivation, gender and microcredit in French Microfinance Institutions and the innovation performance of firms in the technopoles. Beside her academic experience, she is participating regularly in startups competitions organized by SCBS and Technopole de l'Aube en Champagne (TAC) as a finance and entrepreneurship expert and she is coaching students in launching their startups. She is involved also in the student's supervision and counseling during the business games competitions proposed by SCBS.

Anne Berthinier-Poncet is associate professor at Cnam, Paris, where she teaches innovation management and holds a $\mathrm{PhD}$ degree in Management Sciences (Strategy and innovation management). Member of the LIRSA Lab, her main research areas focus on collaborative innovation in the specific context of regional clusters (technopoles, competitiveness clusters), makerspaces (fablabs) and innovation communities. She is particularly interested in topics such as cluster governance, entrepreneurial ecosystems, knowledge management at the collective level, and institutional work. Her fields of investigation are industrial SMEs, the outdoor sport industry and innovation through climate changes ("distributed" metrology/measures of air pollution at the citizen level). Before her academic career, she worked for $>15 y e a r s$ in the industrial sector as international sales and marketing director.

Allane Madanamoothoo holds a PhD degree in Private Law from the University of Toulouse. She joined SCBS in 2011 as a permanent teacher and law researcher after an extensive experience in pedagogy and research. She is also in charge of the law department, coordinating and supervising law courses for all the school's programs (PGE, BBA, GBM), as well as leading the team of part-time law professors. She is also passionate about research focused primarily on biomedical innovation and law. She contributes to these areas through her publications and ongoing communications, both nationally and internationally. She is also regularly involved in startups competitions organized by SCBS and Technopole de l'Aube en Champagne (TAC) as a legal expert and she is helping students when developing their startup's projects with legal advice. Previously, she held also a professional position as Master's thesis Director for a business school managing $>1500$ students.

Wim Vanhaverbeke is professor Digital Innovation and Entrepreneurship at the Surrey Business School (UK). He is also visiting professor at ESADE Business School (Barcelona) and till recently at the National University of Singapore. His current research is focusing on open innovation in SMEs, innovation ecosystems and digital strategies. He published in different international journals such as Organization Science, Research Policy, Journal of Product Innovation Management, California Management Review, Journal of Management, Journal of Management Studies, Small Business Economics, Journal of Business Venturing, Technovation, etc. He was co-editor with Henry Chesbrough and Joel West of "Open Innovation: Researching a New Paradigm" (OUP, 2006) and "New frontiers in open innovation" (OUP, 2014). Furthermore, he published a management book "Managing open innovation in SMEs" (CUP-2017) and an academic volume "Researching open innovation in SMEs" (World Scientific Press2018). He was appointed as member of the Advisory Committee of the Research Center for Technological Innovation of the Tsinghua University from April 2018 till March 2021.

Simona Grama-Vigouroux is an assistant teacher at SCBS since 2013. She is teaching innovation and entrepreneurship. Her main 
teachings areas are related to: business plan, business model, customers' acquisition for new ventures and turnaround management. She obtained a PHD degree at iaelyon School of Management, in Innovation Management. Her main research areas are focused on the human side of open innovation, the impact of support structures as technopoles and business incubators on entrepreneurs' performance and the impact of entrepreneurial competences on the startup success. Beside the academic experience, she is a coach for the entrepreneurship master's program students, helping them to develop projects in relationship with the local firms. Before integrating the educational field, she worked in the online recruitment industry in Romania. 